\title{
ERICH FROMM E A CRÍTICA DA PENA: APROXIMAÇÕES ENTRE PSICANÁLISE E CRIMINOLOGIA DESDE A TEORIA CRÍTICA DA SOCIEDADE
}

\author{
ERICH FROMM AND THE CRITIQUE OF PUNISHMENT: INTERTWINING \\ BETWEEN PSYCHOANALYSIS AND CRIMINOLOGY FROM THE SOCIETY \\ CRITICAL THEORY
}

\section{ERICH FROMM Y LA CRÍTICA DE LA PENA: APROXIMACIONES ENTRE PSICANÁLISIS Y CRIMINOLOGÍA DESDE LA TEORÍA CRÍTICA DE LA SOCIEDAD}

\author{
Salo de CARVALho \\ https://orcid.org/0000-0002-2006-9916 / http://lattes.cnpq.br/4997752549394373 / salo.carvalho@uol.com.br \\ Faculdade Nacional de Direito, UFRJ. \\ Rio de Janeiro, RJ, Brasil \\ Programa de Pós-Graduação em Direito da Universidade La Salle (Unilasalle).
}

Canoas, RS, Brasil

\section{RESUMO}

O ensaio objetiva explorar a obra criminológica de Erich Fromm, fundamentalmente estabelecer parâmetros conceituais para análise e crítica das tradicionais teorias de legitimação da pena a partir da abordagem dialética e interdisciplinar fornecida pela teoria crítica da sociedade. Fromm, ao enlaçar a criminologia (sociologia do desvio e do controle social) à psicanálise e ao questionar, desde fora do direito penal, as funções declaradas da sanção penal nas sociedades contemporâneas, permite redimensionar e atualizar as indagações sobre a funcionalidade do sistema de justiça criminal, mais especificamente sobre os efeitos concretos que a pena produz na prevenção do crime. Neste sentido, a presente investigação é dividida em duas partes: (primeira) a exploração das condições epistemológicas e metodológicas do diálogo entre criminologia e psicanálise; e (segunda) o questionamento dos discursos oficiais de justificação da pena na modernidade

Palavras-chave: Criminologia Crítica; Erich Fromm; Pena; Psicanálise; Teoria Crítica.

\begin{abstract}
The essay aims to explore the criminological work of Erich Fromm, in particular to establish conceptual parameters for the analysis and critique of the traditional theories of the legitimation of the punishment, adopting a dialectical and interdisciplinary approach from the critical theory of society. Fromm, by intertwining criminology (deviance sociology and social control) and psychoanalysis, and by questioning the functions of punishment in contemporary societies from outside the criminal law field, develops and allows a new set of inquiries about the functionality of the criminal justice, particularly regarding the concrete effects of punishment on crime prevention. In this sense, the present investigation is divided into two parts: firstly, the analysis of the epistemological and methodological conditions of the dialogue between criminology and psychoanalysis; and secondly the questioning of official discourses on the justification of punishment in contemporary societies.
\end{abstract}

Keywords: Critical Criminology; Erich Fromm; Punishment; Psychoanalysis; Critical Theory.

\section{RESUMEN}

El ensayo pretende explorar la obra criminológica de Erich Fromm, fundamentalmente establecer algunos parámetros conceptuales para el análisis y crítica de las tradicionales teorías de legitimación de la pena a partir del abordaje dialéctico e interdisciplinario de la teoria crítica de la sociedad. En el caso de las sociedades contemporáneas, permite al redimensionamiento y una actualización de las indagaciones sobre la funcionalidad del sistema de justicia penal, más específicamente sobre los efectos concretos que la pena produce en la prevención del crimen. En este sentido, la presente investigación se divide en dos partes: (primera) la explotación de las condiciones epistemológicas 
y metodológicas del diálogo entre criminología y psicoanálisis; y (segunda) el cuestionamiento de los discursos oficiales de justificación de la pena en la modernidad.

Palabras clave: Criminología Crítica; Erich Fromm; Pena; Psicoanálisis; Teoría Crítica.

\section{SUMÁRIO}

INTRODUÇÃO - ERICH FROMM, A TEORIA CRÍTICA DA SOCIEDADE E A CRIMINOLOGIA CRÍTICA: A JUSTIFICATIVA DO ENSAIO; 1 FROMM ENTRE MARX E FREUD; 2 FROMM: CRIMINÓLOGO CRÍTICO; 3 FROMM: CRIMINOLOGIA CRÍTICA COMO CRÍTICA DA PENA EM “O ESTADO COMO EDUCADOR: SOBRE A PSICOLOGIA DA JUSTIÇA CRIMINAL" (1930); CONCLUSÃO - A ATUALIDADE DA CRÍTICA CRIMINOLÓGICA DE ERICH FROMM; REFERÊNCIAS.

\section{INTRODUÇÃO}

\section{ERICH FROMM, A TEORIA CRÍTICA DA SOCIEDADE E A CRIMINOLOGIA CRÍTICA: A JUSTIFICATIVA DO ENSAIO}

O estudo do que poderíamos identificar como os textos criminológicos do jovem Erich Fromm se insere em uma pesquisa maior que se inicia no pós-doutoramento em direito penal e criminologia, realizado na Universidade de Bolonha, sob a orientação de Massimo Pavarini, e, sequência imediata, no pós-doutoramento em Ética e Filosofia Política, na PUCRS, com Ricardo Timm de Souza. Após a apresentação dos relatórios das pesquisas, em 2015 e 2016, respectivamente, a investigação prosseguiu na elaboração da tese de titularidade em direito penal, na UERJ (concurso suspenso por medida judicial), e na apresentação e desenvolvimento de projetos de pesquisa na Faculdade Nacional de Direito (UFRJ) e, mais recentemente, no Programa de Pós-Graduação (Mestrado e Doutorado) em Direito da Unilasalle (RS). ${ }^{1}$

A série de estudos que se entrelaça desde 2013 procura estabelecer os vínculos conceituais e metodológicos entre (primeiro) o saber desenvolvido pela teoria crítica da sociedade, notadamente as pesquisas dos intelectuais agrupados sob o rótulo de Escola de Frankfurt, e (segundo) a emergência e a consolidação da criminologia crítica a partir do giro epistemológico estabelecido pela teoria do etiquetamento.

Os trabalhos enfatizam, em primeiro plano, os textos dos autores do círculo externo da Escola de Frankfurt, que enfrentaram diretamente temas e problemas criminológicos, como Rusche, Kirchheimer, Neumann e Fromm; e, em segundo plano, as pesquisas dos intelectuais que integraram o núcleo (círculo interno) do Instituto de Pesquisas Sociais, que, embora não

\footnotetext{
${ }^{1} 0$ presente parágrafo foi incluído no texto após a sua aprovação. Não foi encaminhado aos avaliadores para evitar quebra do sistema double blind review adotado pela RECDUFSM.
} 
mergulhem diretamente em objetos criminológicos, fornecem elementos conceituais e metodologias para compreender as relações entre liberdade e segurança, democracia e autoritarismo; os processos de dominação racional e irracional; as formas de adesão ao fascismo; os mecanismos de controle social no interior de estruturas autoritárias de poder; e o desenvolvimento da personalidade autoritária.

No campo da filosofia social, sob a perspectiva da teoria crítica da sociedade, as pesquisas objetivam: (primeiro) analisar teoricamente e atualizar a crítica da violência, em geral, e a crítica da violência de Estado, em particular, elaboradas pelos autores da Escola de Frankfurt; e (segundo) revisitar sua metodologia de análise da personalidade autoritária. Na área da criminologia, sob a orientação da criminologia crítica, as investigações pretendem: (terceiro) resgatar o legado criminológico da teoria crítica na formação e consolidação da criminologia crítica contemporânea; (quarto) revisitar a trajetória da crítica ao punitivismo elaborada por autores formados a partir da matriz frankfurtiana; (quinto) adaptar os instrumentos de análise da personalidade autoritária à metodologia de verificação dos processos de violência institucional elaborada pela psicologia social; (sexto) revisar as metodologias de análise da formação dos processos de violência institucional no Brasil, sobretudo a partir do Golpe de 1964; e (sétimo) elaborar instrumentos para a análise da manutenção dos processos de violência institucional no Brasil, notadamente os aplicáveis às agências do sistema punitivo.

O presente ensaio, de caráter eminentemente teórico, se insere na perspectiva preliminar de revisão da literatura. No entanto, em decorrência da metodologia proposta por Fromm para enfrentar a questão da punição, o estudo ultrapassa o limite da mera historiografia, permitindo atualizar o debate e demonstrar a urgência do pensamento criminológico crítico no atual momento político de crise ou esgotamento ou colapso das democracias ocidentais.

No campo das ciências criminais, há uma narrativa relativamente consolidada sobre o impacto da teoria crítica na formação e no desenvolvimento do pensamento criminológico. Embora a Escola de Frankfurt não possa ser tomada como uma unidade, sendo um verdadeiro contrassenso pretender extrair um sentido unívoco do pensamento pulsante e extremamente rico e variado dos intelectuais identificados com o Instituto de Pesquisa Social, ${ }^{2}$ sua contribuição à criminologia parece estar relativamente estável desde o ponto de vista historiográfico.

A republicação de “Punição e Estrutura Social” (1939), em 1967, é um dos primeiros impulsos para o diálogo entre a teoria crítica e a criminologia radical. Segundo Shecaira, os

2 SOUZA, Ricardo Timm. A Escola e Frankfurt e o Contexto do seu Surgimento. In: SOUZA, Ricardo Timm. Adorno \& Kafka: paradoxos do singular. Passo Fundo: Ifibe, 2010, pp. 53-54. 
primeiros movimentos de retomada do livro nasceram nos Estados Unidos, com a Union of Radical Criminologists (URC, Universidade de Berkeley) e na Inglaterra, com National Deviance Conference $(\mathrm{NDC}) .^{3}$ A recuperação da obra pelos criminólogos radicais, aliada a uma incomum referência de Foucault, em "Vigiar e Punir" (1975), ao "grande livro de Rusche e Kirchheimer", ${ }^{4}$ parece fixar uma espécie de marco de referência para as pesquisas em criminologia crítica. Não por outra razão, a maioria dos textos que se propõe a definir as origens da crítica criminológica acaba, inevitavelmente, por apontar o trabalho de Rushe e Kirchheimer como o seu influxo primeiro.

No entanto, como aponta Nietzsche, a origem é sempre cinza. ${ }^{5}$ A pretensão moderna de estabelecer um marco causal de desenlace de um determinado fenômeno, neste caso, de um fenômeno teórico, é invariavelmente autoritária, pois peca pela exclusão a priori de novas possibilidades e invenções.

No caso da criminologia crítica, embora seja inegável a importância do texto de Rusche e Kirchheimer, notadamente pelas suas qualidades e inovações teóricas e metodológicas, é sempre possível (e estimulante) revisitar as fontes e explorar os trabalhos dos autores da Escola de Frankfurt, que enfrentam, direta ou indiretamente, temas criminológicos. Se uma das principais motivações dos teóricos críticos - motivação que se constitui em uma inquietação ética radical - é apresentar o diagnóstico da modernidade a partir do exame minucioso da anatomia da sua crise e dos sintomas do seu colapso, sobretudo nos estudos sobre a edificação do fascismo e a formação das personalidades autoritárias, a abordagem de problemas tipicamente criminológicos é inevitável.

Ao compartilhar o entendimento de (primeiro) ser a criminologia crítica uma teoria crítica aplicada ao campo das ciências criminais; (segundo) estar a criminologia crítica imersa na perspectiva interdisciplinar que funda a própria ideia de crítica; e (terceiro) ser possível e urgente revisitar as investigações dos autores dos núcleos internos e externos da Escola de Frankfurt, que abordam, ainda que lateralmente, temas criminológicos; o presente ensaio propõe recuperar e atualizar o legado criminológico de Fromm, em especial o presente no " 0 Estado como Educador: sobre a psicologia da Justiça Criminal”. Publicado originalmente em 1930, na "Zeitschrift für Psychoanalytische Pädagogik", de Viena, o trabalho foi submetido à análise dos editores freudianos Heinrich Meng e Ernst Schneider, e do conselho composto por

\footnotetext{
${ }^{3}$ SHECAIRA, Sérgio Salomão. Criminologia. 2. ed. São Paulo: Revista dos Tribunais, 2008, p. 323.

${ }^{4}$ FOUCAULT, Michel. Vigiar e Punir. 8. ed. Petrópolis: Vozes, 1991, p. 27.

${ }^{5}$ NIETZSCHE, Friedrich. Genealogia da Moral. São Paulo: Companhia das Letras, 1998, p. 13.
} 
August Aichhorn, Siegfried Bernfeld, Marie Bonaparte, Sándor Ferenczi, Anna Freud, Fritz Wittels e Jean Piaget.

A contribuição do texto é duplamente inovadora: (primeiro) enlaça a criminologia (sociologia do desvio e do controle social) à psicanálise; (segundo) questiona, a partir da psicanálise, as funções declaradas da pena nas sociedades contemporâneas. Exatamente por isso o presente o ensaio é dividido em duas partes: (primeira) as condições epistemológicas e metodológicas do diálogo interdisciplinar entre sociologia (criminologia, no específico) e psicanálise; e (segunda) as falácias apresentadas como funções oficiais (declaradas) da pena na modernidade e a leitura criminológico-psicanalítica da punição.

\section{FROMM ENTRE MARX E FREUD}

Kevin Anderson, em trabalho de referência sobre a contribuição do jovem Fromm à criminologia, ${ }^{6}$ constata uma espécie de esquecimento, tanto da literatura da Escola de Frankfurt quanto dos estudos criminológicos, dos primeiros artigos publicados no início da década de 30 , exatamente sobre o sistema de justiça criminal. Anderson menciona "Édipo em Innsbruck" (in “Psychoanalystiche Bewegung", 1930); "O Estado como Educador: sobre a psicologia da Justiça Criminal (in "Zeitschrift für Psychoanalytische Pädagogik", 1930); e "Sobre a Psicologia do Criminoso e a Sociedade Punitiva" (in "Imago: Zeitschrift für Anwendung der Psychoanalyse auf die Natur und Geisteswissenchaften”, 1931). Embora sejam considerados estudos bastante originais, Anderson aponta que esta lacuna é presente, inclusive, nos relatos de Mannheim e Gibbons, autores que identificaram as importantes contribuições de “Medo à Liberdade” (1941), considerada uma das maiores obras de Erich Fromm, às teorias psicanalíticas do crime.

A contribuição primeira da Escola de Frankfurt à criminologia crítica parece estar congelada, portanto, na memória de "Punição e Estrutura Social", pesquisa publicada quase uma década depois da série de ensaios do jovem Fromm. Ocorre que "apesar da originalidade, o livro [de Rushe e Kirchheimer] mantém uma perspectiva marxista bastante ortodoxa sobre a história da pena no Ocidente. 0 livro não enfatiza três temas que diferenciam o marxismo da Escola de

\footnotetext{
${ }^{6}$ ANDERSON, Kevin. The Young Erich Fromm's Contribution to Criminology. Justice Quarterly, v. 15, n. 04, 1998, pp. 667-696.

As traduções das citações dos trabalhos publicados em língua estrangeira foram realizadas de forma livre pelo autor. Foram mantidos os grifos originais e eventuais inserções ou destaques são referidas nas notas.
} 
Frankfurt das suas versões mais ortodoxas: a renovada ênfase na dialética hegeliana, a tentativa de combinar teoricamente Marx e Freud e a crítica à cultura de massa."7

Talvez a crítica de Anderson ao trabalho de Rushe e Kirchheimer seja excessiva, notadamente em razão das condições nas quais o texto foi construído e da significativa contribuição de Kirchheimer, no campo da ciência política, às reflexões marcadamente econômicas do manuscrito original apresentado por Rushe a Horkheimer. ${ }^{8}$ No entanto, o alerta relativo à ausência de uma leitura psicanalítica na análise dos fenômenos sociais (crime e pena, no caso), perspectiva interdisciplinar, que é uma das principais contribuições da teoria crítica da sociedade, é extremamente pertinente.

Neste cenário, o ensaio sobre “O Estado como Educador" pretende (primeiro) apontar a contribuição de Fromm ao desenvolvimento do pensamento criminológico crítico junto com outros autores do círculo externo da Escola de Frankfurt (Rushe, Kichheimer e Neumann); e (segundo) identificar o seu legado na intersecção entre criminologia (crítica) e psicanálise.

A exploração segue a orientação proposta por Anderson, ao perceber em Fromm, Rushe e Kirchheimer e Foucault um núcleo comum de proposição e interrogação: "quais as reais funções do sistema de justiça criminal e que efeitos concretos produzem sobre o crime?" A relevância da questão decorre do fato de que em uma era de encarceramento em massa sem precedentes "precisamos examinar de perto como este sistema cruel e irracional não apenas se perpetua, mas também serve como uma maior fonte de legitimação das classes dominantes."10

\footnotetext{
7 "Yet Punishment and Social Structure, despite its originality, remains a fairly orthodox Marxist account of the history of the penal sanction in the West. The book gives no emphasis at all to three issues that differentiate the Frankfurt School's Marxism from more orthodox versions: a renewed emphasis on the Hegelian dialectic, an attempt to combine Marx theoretically with Freud, and a critique of mass culture" (ANDERSON, Kevin. The Young Erich Fromm's Contribution to Criminology. Justice Quarterly, v. 15, n. 04, 1998, p. 668).

80 texto final, redigido exclusivamente por Rusche, estava pronto para publicação em 1935. Todavia, em 1937, Horkheimer designa Kirchheimer para a tarefa de reelaborar o trabalho, "o que faz sem qualquer contato com Rusche." (GARCÍA MENDEZ, Emilio. Pena e Estructura Social en América Latina. Nuevo Foro Penal, v. 22, 1983, p. 762) Melossi informa que Rusche, no período de 1936 e 1939, estava na Palestina exercendo funções docentes na Escola Britânica de Jerusalém. Segundo Melossi, além de uma importante parte sobre a situação carcerária nos Estados Unidos ter sido suprimida, provavelmente em razão dos pareceres de Sellin e Sutherland, há uma substancial alteração na perspectiva dos capítulos elaborados exclusivamente por Kirchheimer (capítulos IX a XIII), sendo o conteúdo de análise deslocado da ênfase socioeconômica à política. Forma de construção do texto. (Melossi apud GARCíA MENDEZ, Emilio. Pena e Estructura Social en América Latina. Nuevo Foro Penal, v. 22, 1983, p. 762).

9 "'What are the real func- tions of a criminal justice system that clearly has little or no effect on crime itself?" (ANDERSON, Kevin. The Young Erich Fromm's Contribution to Criminology. Justice Quarterly, v. 15, n. 04, 1998, p. 693).

10 "We must examine closely how this cruel, irra- tional system not only perpetuates itself but also serves as a major source of legitimation for the dominant classes" (ANDERSON, Kevin. The Young Erich Fromm's Contribution to Criminology. Justice Quarterly, v. 15, n. 04, 1998, p. 693).
} 
Os discursos de legitimação edificam uma linguagem de encobrimento. Não por outra razão, nos termos propostos por Casara, é sempre possível perceber no discurso jurídico "a existência de teóricos dispostos a dar aparência de racionalidade àquilo que é, em essência, irracional (...)."11 A ideologia é, precisamente, esse discurso encobridor, é o discurso que ilude (...)."12 As palavras de justificação, em forma de razão jurídica, “(...) aludem ao sinistro com a digníssima roupagem da racionalidade" ${ }^{13}$, conforme o preciso diagnóstico de Alicia Ruiz.

$\mathrm{Na}$ modernidade, os discursos oficiais sobre a pena e a punição invariavelmente ocuparam esta função ideológica de acomodação e de encobrimento. Coube exatamente à criminologia crítica desenvolver um saber sedicioso que permitiu revelar o real encoberto pelos discursos aparentes das teorias oficiais de justificação.

Fromm, após ingressar na Universidade de Frankfurt, deu seguimento aos estudos acadêmicos em Heidelberg, instituição na qual frequentou aulas de sociologia, filosofia e psicologia e concluiu seu doutorado, em 1922, sob a supervisão de Alfred Weber. Após sua formação acadêmica, ainda em Heidelberg foi introduzido à psicanálise por Frieda Reichmann, pesquisadora que havia inaugurado uma clínica privada de orientação psicanalítica, em $1924 .^{14}$ Fromm realizou sua formação em psicanálise, casou-se com Frieda Reichmann e, em 1927, iniciou o trabalho clínico em seu consultório particular.

A primeira fonte não religiosa a influenciar sua trajetória intelectual, porém, foi Marx, pensador que Fromm afirma ter fornecido "a chave de compreensão da história e a manifestação, em termos seculares, do humanismo radical no qual se expressava a visão messiânica dos profetas do Velho Testamento."15

11 CASARA, Rubens. Estado Pós-Democrático: neo-obscurantismo e gestão dos indesejáveis. Rio de Janeiro: Civilização Brasileira, 2017, p. 87.

12 MARQUES NETO, Agostinho Ramalho. A Censura da Expressão Linguageira e a Hipertrofia do Direito Penal a Serviço do 'Politicamente Correto'. In: VESCOVI, Renata Conde (coord.) Psicanálise e Direito: uma abordagem interdisciplinar sobre ética, direito e responsabilidade. Vitória: ELPV, 2013, p. 61.

${ }^{13}$ RUIZ apud MARQUES NETO, Agostinho Ramalho. O Processo Kafkiano. In: COUTINHO, Jacinto Nelson de Miranda (coord.) Direito e Psicanálise: interseções a partir de 'O Processo' de Kafka. Rio de Janeiro: Lumen Juris, 2007, p. 108.

${ }^{14}$ Os dados biográficos de Erich Fromm foram extraídos sobretudo dos trabalhos de WIGGERSHAUS, Rolf. La Escuela de Fráncfort. Buenos Aires: FCE, 2010, pp. 71-81 e pp. 335-345; JAY, Martin. A Imaginação Dialética: história da Escola de Frankfurt e do Instituto de Pesquisas Sociais (1923-1950). Rio de Janeiro: Contraponto, 2008, pp. 133-194; e FUNK, Rainer. Erich Fromm's Life and Work. In: ANDERSON, Kevin; QUINNEY, Richard (eds.). Erich Fromm and Critical Criminology: beyond the punitive society. Chicago: University of Illinois Press, 2000, pp. 04-18.

15 "The key to the understanding of history and the manifestation, in secular terms, of the radical humanism which was expressed in the messianic vision of the Old Testament prophets" [FROMM apud FUNK, Rainer. Erich Fromm's Life and Work. In: ANDERSON, Kevin; QUINNEY, Richard (eds.). Erich Fromm and Critical Criminology: beyond the punitive society. Chicago: University of Illinois Press, 2000, p. 05[. 
No início dos anos 1930, o interesse por uma abordagem social da psicanálise colocou Fromm em contato com Siegfried Bernfeld e Wilhelm Reich, marxistas freudianos do Instituto de Berlin. Entre 1926 e 1931, Erich Fromm e Frieda Fromm-Reichmann frequentam a casa de Georg Groddeck, em Baden-Baden, onde conhecem Karen Horney e Sándor Ferenczi. Rainer Funk, exassistente, biógrafo, curador do espólio e responsável pelo Instituto Erich Fromm, de Tuebingen, lembra que um dos consensos deste grupo de jovens psicanalistas era o de que “(...) a teoria freudiana do complexo de édipo era insustentável, e que os fatores culturais e sociais poderiam fornecer muito mais consistência em relação à formação psíquica dos instintos."16

A interpretação marxista das hipóteses freudianas permitiu a integração de categorias sociais no conjunto dos elementos doutrinários voltados à dimensão individual:

[...] sendo nos primórdios apenas um método terapêutico, a sua dinâmica interna exigia uma extensão ao homem social para um maior alcance da sua penetração analítica - projeto no qual se empenhou toda uma geração dissidente à ortodoxia freudiana, a 'esquerda psicanalítica', nela se destacando Reich e Marcuse. Com efeito, entre marxismo e psicanálise existe uma possibilidade real de aproximação das suas teses, de que Fromm pretende ser, aliás, uma específica síntese efectiva. ${ }^{17}$

Martin Jay refere que é impossível avaliar, nos dias atuais, a audácia dos primeiros teóricos que propuseram este "casamento antinatural" entre Freud e Marx, notadamente porque “conservadores e radicais concordavam em que o pessimismo básico de Freud acerca das possibilidades de mudança social era incompatível com as esperanças revolucionárias de um verdadeiro marxista." ${ }^{18}$ Segundo Slater, havia um consenso entre os marxistas ortodoxos (leia-se: marxistas-leninistas) de que a psicologia não poderia aprofundar o materialismo histórico e que qualquer tentativa de ampliar, através da psicologia ou da psicanálise, as diretrizes formuladas pelos fundadores Marx e Engels, conduziria a um indesejado ecleticismo, a uma espécie de justaposição de ideias distintas de Hegel, Marx e Freud. ${ }^{19}$

O alerta é válido inclusive porque a ousada introdução da psicanálise na teoria crítica neomarxista do Instituto de Pesquisas Sociais foi, efetivamente, uma tentativa de superação da

16 “(...) Freud's theory of the Oedipus complex was untenable an that cultural and social factors should be given much more weight with regard to the transformation of psychic impulses" [FROMM apud FUNK, Rainer. Erich Fromm's Life and Work. In: ANDERSON, Kevin; QUINNEY, Richard (eds.). Erich Fromm and Critical Criminology: beyond the punitive society. Chicago: University of Illinois Press, 2000, p. 07].

17 REIS, Carlos; CARVALHO, Eurico. Introdução à Leitura de Erich Fromm. Revista da Faculdade de Letras da Universidade do Porto, n. 04, segunda série, 1987, p. 66.

18 JAY, Martin. A Imaginação Dialética: história da Escola de Frankfurt e do Instituto de Pesquisas Sociais (1923-1950). Rio de Janeiro: Contraponto, 2008, p. 133.

${ }^{19}$ SLATER, Phil. Origem e Significado da Escola de Frankfurt: uma perspectiva marxista. Rio de Janeiro: Zahar, 1978, p. 141. 
"camisa-de-força" do marxismo ortodoxo a partir da qualificação interdisciplinar das análises dos fenômenos sociais. A abordagem pouco tradicional produziu, inclusive, importantes resistências dentro do próprio Instituto como, p. ex., as apresentadas por Franz Neumann. ${ }^{20}$

Mas é importante que se diga que a psicanálise freudiana não representou, para a teoria crítica, apenas uma influência ou uma variável que permitisse oxigenar as categorias fundamentais do marxismo. A psicanálise freudiana - única psicologia útil compatível com a teoria crítica, segundo Marcuse ${ }^{21}$-, “é uma interioridade constitutiva, que habita seu corpo teórico e permite à teoria crítica pensar seu objeto, pensar a si mesma e pensar o próprio freudismo enquanto momento da cultura." 22 Conforme Rouanet, "se a Escola de Frankfurt é crítica da cultura e da ideologia, o é, em grande parte, através de Freud, mas também contra Freud." 23

Logo, assim como a teoria crítica não pode ser lida como um corpo teórico uniforme, inexiste uma abordagem unívoca da teoria freudiana nos distintos autores colocados sob o rótulo Escola de Frankfurt. Aliás, praticamente todos os intelectuais frankfurtianos exploraram, com maior ou menor intensidade, as relações entre marxismo e psicanálise, desde os primeiros estudos na fase germânica pré-experiência nazi-fascista com Reich, Fromm e Löwenthal; às pesquisas nos Estados Unidos realizadas por Adorno, Horkheimer e Marcuse; ao retorno do Instituto à Frankfurt com a continuidade das investigações e as novas explorações desenvolvidas por Habermas.

As diferenças entre Fromm e Adorno, p. ex., são significativas e podem ser percebidas desde os "Estudos sobre a Personalidade Autoritária" (1950), aos ensaios "Sobre a relação entre Sociologia e Psicologia" (1955, revisado em 1966), passando pelos aforismos de "Minima Moralia" (1951). Embora Adorno e Fromm concordassem na crítica à teoria freudiana, no sentido de que “(...) os objetivos sociais tinham um papel superior ao dos sexuais, às pretensões de felicidade do indivíduo”, discordavam ao perceber “(...) na atitude de Freud uma falta de bondade que pudesse ser superada com bondade”, ou seja, que “(...) com bondade seria possível ajudar à

20 "Com efeito, uma das divisões básicas entre a geração Grünberg-Grossmann de membros do Instituto e seus sucessores, liderados por Horkheimer, foi o contraste em suas respectivas atitudes para com a psicologia. Em anos posteriores, como veremos, a indiferença geral de Franz Neumann para com a psicologia foi um dos fatores que o impediram de ser plenamente aceito pelo círculo íntimo do Instituto. Quando Neumann finalmente se interessou por Freud, já estava quase no fim da vida, tarde demais para integrar com êxito as duas tradições." [JAY, Martin. A Imaginação Dialética: história da Escola de Frankfurt e do Instituto de Pesquisas Sociais (1923-1950). Rio de Janeiro: Contraponto, 2008, p. 134]

${ }^{21}$ MARCUSE apud SLATER, Phil. Origem e Significado da Escola de Frankfurt: uma perspectiva marxista. Rio de Janeiro: Zahar, 1978, p. 142.

22 ROUANET, Sérgio. Teoria Crítica e Psicanálise. Rio de Janeiro: Tempo Brasileiro, 1986, p. 11.

${ }^{23}$ ROUANET, Sérgio. Teoria Crítica e Psicanálise. Rio de Janeiro: Tempo Brasileiro, 1986, p. 11. 
satisfação das pulsões." ${ }^{24}$ Adorno avança significativamente na crítica ao pensamento freudiano destacando, inclusive, que não é possível imputar a Freud o desprezo pelo concretamente social, mas por se contentar facilmente com a origem social e a fixidez do inconsciente, situação que produziria uma psique abstrata desligada da dialética social. A fixidez e abstração do inconsciente reduziriam a vida psíquica à repetição do passado, modelo naturalista e mecanicista que acabaria, segundo o autor, condenando o pensamento de Freud. ${ }^{25}$ Assim, no que tange às análises realizadas pelos demais pensadores da Escola de Frankfurt, optou-se por apontar, em algumas notas, as convergências e divergências de Fromm com Adorno, notadamente os pontos relacionados à tensa relação entre marxismo e psicanálise, ao problema do desvio social e à formação da personalidade autoritária. Adorno avança sobremaneira nos temas abordados no ensaio, motivo pelo qual as referências se tornaram, em muitos momentos, imprescindíveis.

Neste sentido, é importante delimitar o objeto do presente ensaio, sobretudo em decorrência das distintas formas de recepção da psicanálise freudiana pela teoria crítica. Assim, embora (primeiro) os autores da teoria crítica da sociedade, de forma geral, entendam fundamental completar a análise do fascismo com a psicanálise e a psicologia social analítica ${ }^{26} \mathrm{e}$ (segundo) não existir uma ruptura radical na construção do pensamento do jovem para o maduro Fromm, na segunda parte a abordagem será concentrada principalmente nos textos de final da década de 1920 e início dos anos 1930. Na primeira parte, porém, em razão do enfrentamento de temas que podem ser identificados como criminológicos, serão apresentados alguns trabalhos cronologicamente posteriores, sobretudo "Medo à Liberdade" (1941) e "Psicanálise da Sociedade Contemporânea" (1955).

24 “(...) los objetivos sociales tenían un rango superior al de los sexuales, al de las pretensiones de felicidade del individuo" (WIGGERSHAUS, Rolf. La Escuela de Fráncfort. Buenos Aires: FCE, 2010, p. 337).

“(...) en la actitud de Freud una falta de bondad que hubiera podido ser superada con bondad. (...) con la bondad pudiera se pudiera ayudar a la pulsión a satisfacerse" (WIGGERSHAUS, Rolf. La Escuela de Fráncfort. Buenos Aires: FCE, 2010, p. 337).

Wiggershaus, p. ex., irá dedicar um importante espaço do seu tratado sobre a Escola de Frankfurt para identificar as mais diversas influências da teoria freudiana nos autores e, sobretudo, destacar os pontos de tensão e a crítica de Adorno e Horkheimer à abordagem realizada por Fromm (WIGGERSHAUS, Rolf. La Escuela de Fráncfort. Buenos Aires: FCE, 2010, pp. 335-345).

${ }^{25}$ ADORNO, Theodor W. Estudos sobre Psicologia Social e Psicanálise. In: ADORNO, Theodor W. Ensaios sobre Psicologia Social e Psicanálise. São Paulo: Unesp, 2015, pp. 96-97.

Sobre a crítica de Adorno a Freud, conferir ROUANET, Sérgio. Teoria Crítica e Psicanálise. Rio de Janeiro: Tempo Brasileiro, 1986, pp. 78-98.

${ }^{26}$ Neste sentido, ADORNO, Theodor W. Estudos sobre Psicologia Social e Psicanálise. In: ADORNO, Theodor W. Ensaios sobre Psicologia Social e Psicanálise. São Paulo: Unesp, 2015, pp. 71-72. 
No entanto, sublinhe-se, a exploração da obra de Fromm objetiva, fundamentalmente, estabelecer parâmetros conceituais para o enfrentamento de uma questão específica: a crítica de Fromm às teorias legitimantes da pena, expostas sobretudo no trabalho "O Estado como Educador: sobre a psicologia da Justiça Criminal” (1930).

No ato inaugural do Instituto Psicanalítico de Frankfurt (1929) - primeira organização assumidamente freudiana a estar vinculada a uma Universidade alemã -, Fromm ministra a aula "Psicanálise e Sociologia", posteriormente publicada como ensaio na "Zeitschrift für Psychoanalytische Pädagogik", no mesmo ano. No breve, mas importante artigo, Fromm estabelece suas premissas iniciais para o diálogo com Marx e Freud, a partir de duas indagações: (primeira) qual a aplicação dos distintos métodos e (segunda) qual a contribuição possível entre sociologia e psicanálise? 0 trabalho será posteriormente aprofundado programaticamente em "Método e Função de uma Psicologia Social Analítica", publicado na "Zeitschrift für Sozialforschung", em 1932. ${ }^{2728}$

Fromm inicia sua reflexão indicando que a possibilidade de intersecção entre os saberes psicanalítico e sociológico deve ser precedida por duas ordens de preocupação: (primeira) evitar “(...) o erro de oferecer respostas [eminentemente] psicanalíticas, onde fatos econômicos, técnicos e políticos apontam à explicação real e suficiente das questões sociológicas"; e (segunda) observar que “(...) a sociedade é sempre composta por indivíduos e que estas pessoas concretas com seu fazer, pensar e sentir são os objetos da investigação sociológica (...)"29, isto é, são indivíduos reais e que formam uma sociedade igualmente real, não apenas abstrata. Neste sentido, a contribuição entre os campos se efetivaria na compreensão de como o psiquismo humano atua de maneira causal ou constitutiva no desenvolvimento e na formação social.

27 A primeira formulação relacionada às possibilidades de integração entre materialismo histórico e psicanálise foi o trabalho "Dogma de Cristo", publicado originalmente em 1930. Apesar de destacar que um dos méritos da psicanálise havia sido apagar a falsa distinção entre psicologia social e psicologia individual - "Freud sublinhou que não existe uma psicologia individual do homem isolado do seu meio social, pois um homem isolado não existe” (FROMM, Erich. El Dogma de Cristo. Barcelona: Paidós, 1994, p. 05) -, Freud destacava que os fenômenos psicológicos do grupo deveriam ser compreendidos sobre a base nos mecanismos psíquicos individuais, excluindo a possibilidade de existência de um "caráter social", hipótese que será desenvolvida por Fromm. Assim, nos termos de Slater, "Dogma de Cristo" havia exposto tanto as implicações materialistas quanto as distorções a-históricas da psicanálise freudiana (SLATER, Phil. Origem e Significado da Escola de Frankfurt: uma perspectiva marxista. Rio de Janeiro: Zahar, 1978, p. 142).

Apesar deste estudo inicial, Slater refere que "Método e Função de uma Psicologia Social Analítica" foi, efetivamente, o primeiro ensaio programático de Fromm (SLATER, Phil. Origem e Significado da Escola de Frankfurt: uma perspectiva marxista. Rio de Janeiro: Zahar, 1978, p. 142).

${ }^{28}$ Sobre o tema, Adorno, em 1966, redige um longo e consistente estudo intitulado "Sobre a Relação entre Sociologia e Psicologia", no qual propõe uma psicologia social psicanaliticamente orientada (ADORNO, Theodor. Ensaios sobre Psicologia Social e Psicanálise. São Paulo: Unesp, 2015, pp. 71-135).

${ }^{29}$ FROMM, Erich. Psicanálise e Sociologia. Revista Espaço Acadêmico, n. 110, 2010, p. 01. 
A experiência humana não poderia ser simplesmente cindida entre um "ser social" e um "eu individual". Assim, da mesma forma que as pessoas não possuem uma "alma individual" separada da uma "alma de massa", o objeto da psicanálise (indivíduo) não poderia ser isolado do sociológico (coletividade). As pessoas agem como eu individual e como ser social, pois "não há duas almas no ser humano, mas apenas uma, na qual vigoram os mesmos mecanismos e leis." 3031

Se a sociedade é composta por indivíduos vivos, seria errôneo reduzir a psicanálise à esfera da psicologia individual e negar a sua aplicabilidade aos fenômenos sociais (política e consciência de classe, p. ex.). Assim, para Fromm,

[...] o fato de um fenômeno ser estudado em Sociologia não significa, certamente, que não possa ser um objeto de Psicanálise (...). A tese de que a Psicologia só trata do indivíduo, ao passo que a Sociologia só se ocupa da 'sociedade', é falsa. Pois assim como a Psicologia diz sempre respeito a um indivíduo socializado, também a Sociologia trata sempre de um grupo de indivíduos cuja estrutura e mecanismos psíquicos têm de ser levados em consideração. ${ }^{32}$

Um dos problemas essenciais na investigação do autor seria, portanto, desde o ponto de vista psicanalítico, relativo ao papel dos impulsos na formação da comunidade. Mas ao mesmo tempo em que seria fundamental apontar o modo pelo qual o inconsciente humano atua na estruturação da sociedade, deve-se reconhecer, desde a perspectiva sociológica, que o indivíduo igualmente só existe como homem socializado, que o seu psiquismo é formado a partir das relações e interações sociais, o que permite questionar como e em que nível as alterações na estrutura social impactam o processo de desenvolvimento individual.

$\mathrm{Na}$ perspectiva de a psicanálise demonstrar de como a sociedade é, de fato, formada por indivíduos, e de a sociologia verificar como o indivíduo e a família são produtos de uma estrutura social ímpar, na modernidade ocidental representada pela sociedade capitalista, os impulsos (instintos) individuais só poderiam ser percebidos em uma interação dialética com as experiências vitais sócio-históricas. ${ }^{33}$ Não por outro motivo, a teoria social que apresentaria um

\footnotetext{
${ }^{30}$ FROMM, Erich. Psicanálise e Sociologia. Revista Espaço Acadêmico, n. 110, 2010, p. 01.

31 "Pois a 'sociedade' também consiste em indivíduos vivos, que devem estar sujeitos às mesmas leis psicológicas descobertas pela Psicanálise no indivíduo." (FROMM, Erich. Método e Função de uma Psicologia Social Analítica. In: FROMM, Erich. A Crise da Psicanálise: Freud, Marx e a Psicologia Social. 2 ed. Rio de Janeiro: Zahar, 1977, p. 138)

32 FROMM, Erich. Método e Função de uma Psicologia Social Analítica in FROMM, Erich. A Crise da Psicanálise: Freud, Marx e a Psicologia Social. 2 ed. Rio de Janeiro: Zahar, 1977, p. 138/9.

${ }^{33}$ SLATER, Phil. Origem e Significado da Escola de Frankfurt: uma perspectiva marxista. Rio de Janeiro: Zahar, 1978, p. 143.
} 
maior grau de sintonia e intimidade com a psicanálise seria exatamente o materialismo histórico.

A exploração analítica proposta pela psicologia social consistiria, portanto, na apreensão do verdadeiro nó conceitual entre marxismo e psicanálise: “compreender o dispositivo instintivo de um grupo, seu comportamento libidinal e predominantemente inconsciente, em função da sua estrutura sócio-económica."34 A indivisibilidade do objeto ("alma individual” e “alma de massa”) conduziria, em consequência, à impossibilidade de uma cisão metodológica:

[...] do condicionamento mútuo entre ser humano e sociedade resultam vários importantes problemas, onde não se pode se referir à aplicação de um método ao outro, mas onde um único fato, sendo um psicológico quanto sociológico, deve ser investigado por ambos os métodos e entendido por ambos os lados." 35

Apesar do fato de, neste momento, os Manuscritos de Paris ainda não estarem em domínio público - os "Manuscritos Econômico-Filosóficos" foram publicados na Alemanha apenas em 1932 -, Anderson percebe a confluência de Fromm à sua perspectiva antropológica: “(...) Fromm interpreta Marx em uma perspectiva humanista, de forma subjetivamente-centrada, mais do que em termos de um materialismo determinista." 3637

Ao finalizar o estudo sobre as condições de possibilidade epistemológicas da psicologia social analítica, no qual desenvolve e aprofunda os problemas apresentados na conferência de 1929, Fromm expõe de forma bastante objetiva suas conclusões: (primeira) o método da psicologia social analítica seria o da psicanálise freudiana clássica aplicada aos fenômenos sociais - "explica as atitudes psíquicas compartilhadas e socialmente relevantes, em função do processo de adaptação ativa e passiva do mecanismo dos impulsos às condições de vida socioeconômica da sociedade"; ${ }^{38}$ e (segundo) a tarefa da psicologia social analítica seria a de

\footnotetext{
${ }^{34}$ FROMM, Erich. Método e Função de uma Psicologia Social Analítica. In: FROMM, Erich. A Crise da Psicanálise: Freud, Marx e a Psicologia Social. 2 ed. Rio de Janeiro: Zahar, 1977, p. 141.

No mesmo sentido, conferir REIS, Carlos; CARVALHO, Eurico. Introdução à Leitura de Erich Fromm.

Revista da Faculdade de Letras da Universidade do Porto, n. 04, segunda série, 1987, p. 67.

${ }^{35}$ FROMM, Erich. Psicanálise e Sociologia. Revista Espaço Acadêmico, n. 110, 2010, p. 02.

36 "Fromm interpreted Marx in a humanistic, subject-centered manner rather than in that of a deterministic materialism" (ANDERSON, Kevin. The Young Erich Fromm's Contribution to Criminology. Justice Quarterly, v. 15, n. 04, 1998, p. 674).

37 "Fromm sempre enfatizou as implicações antropológicas dos Manuscritos Econômico-Filosóficos de Marx. Nesse aspecto, aproximou-se mais de Marcuse (pelo menos antes da entrada deste nos assuntos do Instituto) do que de Horkheimer e Adorno)." [JAY, Martin. A Imaginação Dialética: história da Escola de Frankfurt e do Instituto de Pesquisas Sociais (1923-1950). Rio de Janeiro: Contraponto, 2008, p. 133]

38 FROMM, Erich. Método e Função de uma Psicologia Social Analítica. In: FROMM, Erich. A Crise da Psicanálise: Freud, Marx e a Psicologia Social. 2 ed. Rio de Janeiro: Zahar, 1977, p. 161.
} 
analisar os impulsos libidinais socialmente relevantes - "descrever a estrutura libidinal de uma dada sociedade e explica[r] a origem desta estrutura, assim como a sua função social."39

Todo grupo social possuiria, para Fromm, uma estrutura libidinal própria, não contingente, mas necessária e dependente das condições socioeconômicas e das relações de poder. Conforme demonstra Rouanet, esta estrutura libidinal típica, comum a todos os homens em determinado espaço e tempo, exerceria uma função decisiva na preservação das estruturas vigentes, pois "é ela que estabelece os vínculos afetivos pelos quais as classes oprimidas se relacionam com as classes dirigentes, levando as primeiras a aceitar passivamente a sua opressão."40

Nota-se, portanto, que as primeiras reflexões de Fromm sobre as possibilidades epistemológicas e metodológicas da aproximação entre sociologia (Marx) e psicanálise (Freud) apontam para uma sintonia que pode ser expressa no fato de ambos os campos de conhecimento optarem pelo materialismo, ou seja, abdicarem de uma compreensão idealista ou metafísica para concentrar suas análises nas necessidades reais e terrenas dos homens.

Todavia, se a psicologia freudiana e o materialismo histórico concordam que “[...] a consciência não [é] o motor principal da história, mas o reflexo de 'outras forças ocultas'", ${ }^{41}$ entram em um conflito aparentemente intransponível na discussão acerca da natureza dos fatores que condiciona esta consciência do homem: "o materialismo histórico vê a consciência como expressão da existência social; a Psicanálise considera-a determinada por impulsos instintivos." 42 Se toda a sociedade possuía uma estrutura libidinal própria, entendida como a combinação dos instintos humanos básicos e dos fatores sociais, a psicologia social deveria, examinar “(...) de que modo esta estrutura libidinal agiria como cimento da sociedade e de que modo afetava a autoridade política." 43

Afastando-se de Freud, Fromm denomina caráter social esta soma de características comuns das pessoas inseridas na mesma situação social e condição de classe. 0 caráter social estabeleceria um

39 FROMM, Erich. Método e Função de uma Psicologia Social Analítica. In: FROMM, Erich. A Crise da Psicanálise: Freud, Marx e a Psicologia Social. 2 ed. Rio de Janeiro: Zahar, 1977, p. 161.

${ }^{40}$ ROUANET, Sérgio. Teoria Crítica e Psicanálise. Rio de Janeiro: Tempo Brasileiro, 1986, p. 53.

${ }^{41}$ SLATER, Phil. Origem e Significado da Escola de Frankfurt: uma perspectiva marxista. Rio de Janeiro: Zahar, 1978, p. 144.

42 FROMM, Erich. Método e Função de uma Psicologia Social Analítica. In: FROMM, Erich. A Crise da Psicanálise: Freud, Marx e a Psicologia Social. 2 ed. Rio de Janeiro: Zahar, 1977, p. 139.

43 JAY, Martin. A Imaginação Dialética: história da Escola de Frankfurt e do Instituto de Pesquisas Sociais (1923-1950). Rio de Janeiro: Contraponto, 2008, p. 140. 
[...] padrão normativo em função do qual o processo de socialização modela as personalidades individuais. 0 interesse do grupo (ou da classe dominante) é formulado sob a forma de ideologia, a qual se cristaliza como caráter social, e este, internalizado no curso do processo de socialização, produz um caráter individual. ${ }^{44}$

A função do caráter social seria a de transformar as necessidades sociais em impulsos individuais. Por isso, para Fromm, o caráter social estabelece uma espécie de mediação entre a base econômica e a ideologia. ${ }^{45} \mathrm{Em}$ consequência, experiências, como a violência e o autoritarismo, não poderiam ser explicadas pela simples analogia com os fenômenos neuróticos individuais.

Outro ponto relevante, e que se insere nas críticas de Fromm à Freud, diz respeito à tendência de a psicanálise normalizar os valores e os princípios da sociedade burguesa (trabalhar, procriar e gozar). Conforme a psicanálise freudiana, a neurose, como sintoma ou traço do caráter, resultaria da adaptação defeituosa dos impulsos instintivos dos indivíduos à realidade, situação que definiria comportamentos “desviantes” ou "anormais". Para Fromm, a psicanálise restaria prisioneira da moral burguesa e patriarcal a partir do momento em que o analista, supondo atuar de forma neutra, compartilha acriticamente seus valores e induz o agir conformista de um indivíduo iludido com uma falsa autonomia. ${ }^{46}$

Nas lições de Jay, "a tolerância burguesa era sempre contraditória: no plano consciente, era relativista e neutra, mas, subconscientemente, destinava-se a preservar o status quo. A psicanálise, sugeriu Fromm, compartilhava o caráter hipócrita desse tipo de tolerância (...)." ${ }^{47} 48$ Neste sentido, o indivíduo completamente adaptado, que não apresenta qualquer

${ }^{44}$ ROUANET, Sérgio. Teoria Crítica e Psicanálise. Rio de Janeiro: Tempo Brasileiro, 1986, p. 54.

45 "A base gera o caráter social, que condiciona as ideias e valores, que constituem a ideologia; mas essas ideias e valores, numa ação de retorno, refluem para o caráter social, reforçando-o, o que por vez consolida a base econômica." (ROUANET, Sérgio. Teoria Crítica e Psicanálise. Rio de Janeiro: Tempo Brasileiro, 1986, p. 55)

${ }^{46}$ Adorno, ao enfrentar este problema, afirma que aquele que na atualidade não se comporta segundo a racionalidade econômica, não naufraga imediatamente, mas projeta um rebaixamento socioeconômico e "torna visível o caminho para o associal, para o criminoso: a recusa de colaborar torna suspeito e expõe à vingança social quem não precisa ainda passar fome e dormir sob as pontes. 0 medo [Angst] de ser excluído, a sanção social do comportamento econômico, internalizou-se há muito através de outros tabus, sedimentando-se no indivíduo." (ADORNO, Theodor W. Estudos sobre Psicologia Social e Psicanálise. São Paulo: Unesp, 2015, p. 77).

47 JAY, Martin. A Imaginação Dialética: história da Escola de Frankfurt e do Instituto de Pesquisas Sociais (1923-1950). Rio de Janeiro: Contraponto, 2008, p. 145.

No mesmo sentido, conferir WIGGERSHAUS, Rolf. La Escuela de Fráncfort. Buenos Aires: FCE, 2010, p. 336.

48 Segundo Fromm, uma das ideias mais difundidas no campo da psicologia em relação às expectativas sociais e aos critérios de definição do comportamento ajustado “(...) quer fazer crer que a sociedade ocidental contemporânea, e, de modo especial, o 'estilo de vida americano', corresponde às necessidades 
manifestação de desconforto, tristeza ou raiva com a sua condição e/ou que nunca subverteu as normas sociais, é precisamente aquele que poderia ser diagnosticado como menos sadio psiquicamente, se comparado ao neurótico. ${ }^{49} 50$

Rouanet identifica com precisão que é na exploração dos elementos subjetivos que permitiram a emergência do nacional-socialismo que o jovem Fromm irá aplicar de forma mais convincente a sua teoria do caráter social. ${ }^{51} \mathrm{O}$ problema que move Fromm - muito similar ao proposto quase quatro séculos antes por Étienne de La Boétie, no “Discurso da Servidão Voluntária" $(1548)^{52}$ - é relativo à identificação das condições pelas quais as pessoas aceitaram, pacífica e resignadamente, a opressão fascista.

Embora o problema da psicologia da autoridade já tivesse sido abordado por Fromm no projeto de pesquisa “Estudos sobre a Autoridade e a Família” (1936), é com o seu afastamento do Instituto de Pesquisas Sociais, em 1939, que o pensador ganha autonomia, notadamente em

mais profundas da natureza humana, e que a adaptação a esse tipo de vida significa saúde mental e maturidade. [Nesta perspectiva] A psicologia social, em vez de ser um instrumento de crítica à sociedade, converte-se, desse modo, em uma apologia ao status quo." (FROMM, Erich. Psicanálise da Sociedade Contemporânea. São Paulo: Círculo do Livro, 1985, p. 74)

49 WIGGERSHAUS, Rolf. La Escuela de Fráncfort. Buenos Aires: FCE, 2010, p. 341.

50 Temas relativos à "patologia da normalidade" são desenvolvidos sobretudo na obra "Psicanálise da Sociedade Contemporânea" (1955), considerado pelo próprio Fromm como continuidade de "Medo à Liberdade", apesar do intervalo de quase 15 anos.

Segundo Fromm, a psiquiatria e a psicologia ortodoxas entendem o problema da saúde mental a partir da análise estatística do número dos indivíduos desajustados, "e não do possível desajustamento da própria cultura." (FROMM, Erich. Psicanálise da Sociedade Contemporânea. São Paulo: Círculo do Livro, 1985, p. 17)

No entanto, o autor procura inverter esta concepção estatística da normalidade, ao postular que a atitude mentalmente sadia seria a do próprio questionamento das necessidades criadas pela cultura, e não aquelas condutas que contrariam à satisfação das exigências sociais. Assim, o problema da "normalidade" é alterado: "a saúde mental passa a avaliar-se pelo grau de adaptação da sociedade à natureza humana, e não o contrário." (REIS, Carlos; CARVALHO, Eurico. Introdução à Leitura de Erich Fromm. Revista da Faculdade de Letras da Universidade do Porto, n. 04, segunda série, 1987, p. 69) 0 conceito de natureza humana referido por Fromm, conforme trabalhado ao longo do texto, é dado a partir da tensa intersecção entre os campos sociológico (Marx) e psicanalítico (Freud).

Neste cenário, Fromm destaca que a análise da saúde mental não pode ser reduzida ao critério da adaptabilidade do ser individual às expectativas do corpo social, mas, ao contrário, "deve ser definida como adaptação da sociedade às necessidades do homem (...). O fato de o indivíduo estar ou não mentalmente sadio não é primordialmente um assunto individual, pois depende da estrutura da sociedade. Uma sociedade sadia desenvolve a capacidade do homem para amar o próximo, para trabalhar criadoramente, para desenvolver sua razão e sua objetividade, para ter um sentimento de si baseado em suas próprias capacidades produtivas. Uma sociedade insana é aquela que cria hostilidade mútua e desconfiança, que transforma o homem em instrumento de uso e exploração para outros, que o priva do sentimento de si mesmo (...)." (FROMM, Erich. Psicanálise da Sociedade Contemporânea. São Paulo: Círculo do Livro, 1985, p. 73/4)

${ }^{51}$ ROUANET, Sérgio. Teoria Crítica e Psicanálise. Rio de Janeiro: Tempo Brasileiro, 1986, p. 55.

52 LA BOÉTIE, Etienne de. O Discurso da Servidão Voluntária. 3. ed. São Paulo: Brasiliense, 1986, pp. $12-$ 13. 
relação às críticas ao pensamento freudiano, para desenvolver as ideias que irão se concretizar em “Medo à Liberdade” (1941).

A questão central analisada na obra é relativa ao dilema moderno entre liberdade e segurança, cujas consequências se projetam em modelos específicos de organização e de dominação nas sociedades capitalistas. Democracia e autoritarismo, portanto, são reflexos imediatos das decisões tomadas pelo corpo social em relação às formas de controle admitidas e que podem conduzir à aceitação coletiva e voluntária da opressão e, em consequência, à legitimação de uma autoridade fascista.

Afirma Fromm, como tese central do livro, que

[...] o homem moderno, emancipado dos grilhões da sociedade pré-individualista que simultaneamente the davam segurança e o cerceavam, não alcançou a liberdade na acepção positiva de realização do seu eu individual: isto é, a manifestação de suas potencialidades intelectuais, emocionais e sensoriais. ${ }^{53}$

Se a conquista da liberdade assegurou ao homem moderno a autonomia da razão, por outro lado circunscreveu o seu espírito na angústia e na impotência do isolamento. As alternativas à condição insuportável de solidão seriam as de progredir para a liberdade positiva (alternativa libertária) ou as de recuar e desistir da liberdade, submetendo-se a novas formas de dependência (fuga totalitária). Neste sentido, “Medo à Liberdade" explora "os fatores dinâmicos da estrutura do caráter do homem moderno que o levaram a querer desistir da liberdade nos países fascistas e que predominam de forma tão generalizada entre milhões de nossa própria gente." 54

Livre $e$ isolado, esta nova condição do indivíduo moderno surge como uma espécie de maldição. Fromm identifica duas espécies de manifestação da liberdade que explicariam esta dualidade: (primeiro) a liberdade negativa (ou liberdade de) que representa a ruptura histórica do homem iluminista com a opressão da autoridade revelada; e (segundo) a liberdade positiva (ou liberdade para) que significa a possibilidade de realização plena da personalidade individual através da expressão plena das capacidades racionais e emocionais. No diagnóstico de Fromm, a falta de equilíbrio entre liberdade negativa (emancipação da opressão) e liberdade positiva (máxima expressão da liberdade), “conduziu, na Europa, a uma fuga apavorada da liberdade para o jugo de novos grilhões ou, no mínimo, para um indiferentismo total." 55 Os mecanismos

\footnotetext{
53 FROMM, Erich. Medo à Liberdade. 14. ed. Rio de Janeiro: Guanabara, 1986, p. 10.

${ }^{54}$ FROMM, Erich. Medo à Liberdade. 14. ed. Rio de Janeiro: Guanabara, 1986, p. 15.

55 FROMM, Erich. Medo à Liberdade. 14. ed. Rio de Janeiro: Guanabara, 1986, p. 39.
} 
culturais de fuga da liberdade identificados por Fromm seriam o autoritarismo, a destrutividade e o conformismo.

O mecanismo autoritário revelaria uma orientação ambígua em relação ao poder, pois apresentaria uma tendência não apenas à submissão, mas também à dominação. A personalidade autoritária afirma-se como dominadora contra aqueles que considera mais fracos e, inversamente, submissa em relação aos poderosos. Ocorre que os anseios à submissão e à dominação, encontrados nos instintos masoquistas e sádicos, estariam presentes não apenas nas pessoas neuróticas, mas igualmente nas consideradas normais.

Os impulsos masoquistas, embora na aparência sejam disfarçados como amor ou lealdade, manifestam-se, com frequência, nos sentimentos de inferioridade, impotência e insignificância individual; as tendências sádicas são reveladas através da dominação (tornar os outros dependentes de si), da exploração (usar o outro em benefício próprio) e da imposição de dor, sofrimento ou humilhação física ou psicológica. O desejo, na perversão masoquista, é o de

ser tornado fraco 'moralmente', pelo fato de ser tratado como uma criança ou de ser repreendido ou humilhado de qualquer maneira. Na perversão sádica encontramos a satisfação oriunda de atitudes correspondentes, isto é, de magoar outras pessoas fisicamente, de amarrá-las com cordas ou correntes, ou de humilhá-las por meio de palavras ou atos. ${ }^{56}$

Ocorre que ambos os impulsos (sádicos e masoquistas) auxiliam o indivíduo na fuga dos insuportáveis sentimentos de solidão e de impotência. Assim, se o autoritarismo seria a "tendência para renunciar à independência do próprio ego individual e fundi-lo com alguém ou com algo, no mundo exterior, a fim de adquirir a força de que o ego individual carece" ${ }^{57}$, o encontro de determinados padrões culturais, “como a submissão ao 'chefe' na ideologia fascista", ${ }^{58}$ poderia confortar o sujeito solitário, transmitindo-lhe uma segurança libertadora. Sentimento de segurança que, invariavelmente, é compartilhado com a massa de indivíduos que se encontram nas mesmas condições de isolamento.

Nestas circunstâncias é que Fromm afirma ser o caráter sadomasoquista constitutivo da base pulsional da personalidade autoritária. Em sentido oposto à condição assustadora da liberdade, as pessoas são conduzidas voluntariamente ao porto seguro e confortável das respostas totalizadoras e das ações padronizadas. Qualquer forma de existência desviante ou alternativa representaria, pois, uma ameaça que deve ser eliminada.

\footnotetext{
${ }^{56}$ FROMM, Erich. Medo à Liberdade. 14. ed. Rio de Janeiro: Guanabara, 1986, p. 123.

${ }^{57}$ FROMM, Erich. Medo à Liberdade. 14. ed. Rio de Janeiro: Guanabara, 1986, p. 118.

${ }^{58}$ FROMM, Erich. Medo à Liberdade. 14. ed. Rio de Janeiro: Guanabara, 1986, p. 126.
} 
$\mathrm{Na}$ análise do fenômeno nazista, Fromm sustenta que o caráter sadomasoquista foi representativo de considerável parcela da classe média inferior da Alemanha. Foi exatamente nestes extratos médios que a ideologia fascista exerceu maior fascínio. Ocorre que estes impulsos sadomasoquistas, diferentes da resposta padrão da psicanálise, foram manifestados em pessoas que não poderiam ser classificadas como neuróticas. Assim, em decorrência de o termo sadomasoquismo ser frequentemente associado às formas de perversão e neurose, Fromm utiliza a categoria analítica caráter autoritário para identificar os impulsos sadomasoquistas latentes ou manifestos presentes nas pessoas normais. E a justificativa da adequação do termo parece extremamente pertinente:

esta terminologia [caráter autoritário] justifica-se porque a pessoa sadomasoquista sempre é assinalada por sua atitude face à autoridade. Ela admira a autoridade e mostra-se inclinada a submeter-se a esta, mas, ao mesmo tempo, deseja ser, ela mesma, uma autoridade e fazer com que os outros se the submetam. ${ }^{59}$

Se Fromm a princípio enfatiza os aspectos individuais ou coletivos das manifestações dos impulsos sadomasoquistas para definir o caráter autoritário, ao concluir altera o foco micro (indivíduo e sociedade) para o macrossociológico (Estado) ao indicar haver outra razão para escolher esta denominação:

o sistema fascista chama-se a si mesmo de autoritário por causa do papel dominante da autoridade em sua estrutura político social. Pelo nome 'caráter autoritário' subentendemos o que ele representa na estrutura de personalidade que constitui as fundações humanas do fascismo. ${ }^{60}$

Neste ponto, Fromm justifica a abordagem materialista histórica na qualificação da leitura psicanalítica do fenômeno nazista. A tese proposta, e que sintetiza a reflexão epistemológica e metodológica acerca da possibilidade de aproximação da psicanálise (Freud) com a sociologia (Marx), se desenvolve a partir da relação dialética entre a psicologia individual e as psicologias e sociologias institucionais. Segundo o autor, nenhuma explicação que enfatize os fatores políticos ou econômicos do nazismo, excluindo os psicológicos, está correta (e viceversa), pois

o nazismo é um problema psicológico, mas os próprios fatores psicológicos têm de ser interpretados como sendo moldados por fatores sócio-econômicos; o

${ }^{59}$ FROMM, Erich. Medo à Liberdade. 14. ed. Rio de Janeiro: Guanabara, 1986, p. 134.

${ }^{60}$ FROMM, Erich. Medo à Liberdade. 14. ed. Rio de Janeiro: Guanabara, 1986, p. 134. 
nazismo é um problema econômico e político, porém o fascínio por ele exercido sobre um povo inteiro tem de ser interpretado em bases psicológicas. ${ }^{61}$

A decadência econômica e o capitalismo monopolista produziram profundos efeitos psicológicos na população; e se as condições psicológicas não determinaram a experiência nazista, constituíram o solo de sua emanação.

Apesar da qualidade e da originalidade da tese sobre personalidade autoritária, em especial sobre o caráter sadomasoquista na formação das condições de possibilidade para a ascensão do nacional-socialismo na Alemanha, há uma evidente resistência aos estudos de Fromm pelos demais membros da Escola de Frankfurt. Não por outra razão, p. ex., em “Behemoth" (1942, incluindo o apêndice de 1944),

não há uma clara referência de que Neumann aceitasse a ideia do caráter sadomasoquista enunciado por Fromm. Além disso, ao analisar o fracasso da classe trabalhadora durante a República de Weimar, Neumann desconheceu o estudo de Fromm sobre a mentalidade ambivalente do proletário alemão. ${ }^{62}$

\section{FROMM: CRIMINÓLOGO CRÍTICO}

Anderson sustenta que após os textos de 1930 e 1931, ensaios que enfrentavam temas especificamente criminológicos - lembre-se: (primeiro) psicologia do criminoso (“Édipo em Innsbruck", 1930); (segundo) pena e punição ("O Estado como Educador: sobre a psicologia da Justiça Criminal, 1930), (terceiro) comportamento criminoso e Justiça Criminal ("Sobre a Psicologia do Criminoso e a Sociedade Punitiva”, 1931) -, "o jovem marxista-freudiano Erich Fromm, crítico do sistema de Justiça Criminal, parece ter desaparecido no oblívio."63 Segundo Anderson, Fromm aparentemente nunca mais teria retomado estes temas, não tendo sequer incorporado os artigos em coletâneas posteriores.

A afirmação, embora não possa ser qualificada como incorreta, merece ser problematizada, não apenas porque diz respeito às dimensões epistemológicas e metodológicas

${ }^{61}$ FROMM, Erich. Medo à Liberdade. 14. ed. Rio de Janeiro: Guanabara, 1986, p. 167.

$62 \mathrm{JAY}$, Martin. A Imaginação Dialética: história da Escola de Frankfurt e do Instituto de Pesquisas Sociais (1923-1950). Rio de Janeiro: Contraponto, 2008, p. 217.

No mesmo sentido, conferir WIGGERSHAUS, Rolf. La Escuela de Fráncfort. Buenos Aires: FCE, 2010, p. 336.

63 "The young Erich Fromm's Freudian Marxist critiques of the criminal justice system seem to have disappeared into oblivion" (ANDERSON, Kevin. The Young Erich Fromm's Contribution to Criminology. Justice Quarterly, v. 15, n. 04, 1998, p. 667). 
da criminologia, mas porque parece desconsiderar exatamente o giro paradigmático provocado pela teoria crítica na criminologia: a constituição de um saber criminológico antipositivista, antiautoritário, macrossociológico e interdisciplinar.

Aniyar de Castro e Codino, ao analisarem o impacto da Escola de Frankfurt nas ciências criminais, destacam algumas funções bastante evidentes da teoria crítica: (primeira) desmascarar todo tipo de legitimação ideológica e (segundo) realizar uma discussão racional de toda a relação fática de poder. Assim, ao colocar no centro da discussão a dimensão dos poderes (“o poder, portanto, se senta no banco dos réus"), ${ }^{64}$ a teoria crítica aprimora uma espécie de dúvida metodológica sobre as suas formas de manifestação, sobre o exercício dos poderes mesmos. Não por outra razão, na elaboração do decálogo do pensamento criminológico de inspiração frankfurtiana, Aniyar de Castro e Codino salientam a centralidade da crítica ao autoritarismo como refutação de relações de poder verticais e centralizadas e, neste contexto, destacam nominalmente a importância da denúncia realizada por Fromm em "Medo à Liberdade". ${ }^{65}$

Ocorre que este questionamento das relações fáticas de poder, como objeto de exploração da criminologia crítica, pode ser ampliado para trabalhos posteriores de Fromm, os quais (primeiro) procuram apresentar importantes inovações relacionadas ao saber criminológico tradicional (microcriminologia) - “Psicanálise da Sociedade Contemporânea” (1955) ${ }^{66}$ e “Anatomia da Destrutividade Humana” (1973) ${ }^{67}$-; e (segundo) pretendem expor, como objeto central ou como pano de fundo, as formas de constituição da relação entre indivíduo e Estado ou, em última análise, a tensão entre liberdade e autoridade (segurança), democracia e autoritarismo.

Pavarini, na abertura de “Controle e Dominação" (1980), alertava, de forma bastante clara e precisa, para o fato de que a reflexão criminológica estará sempre orbitando a questão da (des)ordem social, em última instância, a relação entre indivíduo e autoridade, a tensão

\footnotetext{
${ }^{64}$ ANIYAR DE CASTRO, Lola; CODINO, Rodrigo. Manual de Criminología Sociopolitica. Buenos Aires: Ediar, 2013, p. 240.

${ }^{65}$ ANIYAR DE CASTRO, Lola; CODINO, Rodrigo. Manual de Criminología Sociopolitica. Buenos Aires: Ediar, 2013, p. 241.

${ }^{66}$ Neste sentido, p. ex., (primeiro) os estudos sobre normalidade, desvio e doença mental (FROMM, Erich. Psicanálise da Sociedade Contemporânea. São Paulo: Círculo do Livro, 1985, pp. 23-30 e pp. 69-78); e (segundo) as análises comparativas entre taxas de suicídio e homicídios na população adulta (FROMM, Erich. Psicanálise da Sociedade Contemporânea. São Paulo: Círculo do Livro, 1985, pp. 15-22).

${ }^{67} \mathrm{Na}$ sequência, p. ex., (terceiro) as pesquisas sobre as condições para o desenvolvimento do caráter sádico e necrofílico, nos estudos clínicos de Stalin, Himmler e Hitler (FROMM, Erich. Anatomia da Destrutividade Humana. 2. ed. Rio de Janeiro: Guanabara, 1987, pp. 376-432 e pp. 435-574); e (quarto) a revisão da teoria da agressividade (FROMM, Erich. Anatomia da Destrutividade Humana. 2. ed. Rio de Janeiro: Guanabara, 1987, pp. 435-574).
} 
entre desvio e obediência e as formas (verticais e horizontais) e os instrumentos (formais e informais) de controle social. ${ }^{68}$ Neste sentido, a afirmação de Anderson de que Fromm não retomou, ao longo de sua trajetória de pesquisa, temas próprios do saber criminológico, só faria sentido se o objeto da criminologia fosse encapsulado no crime, no criminoso e na resposta jurídica ao desvio punível (pena e punição). Só se justificaria, portanto, desde uma leitura microcriminológica, ou seja, desde um marco positivista centrado na questão causal (etiológica). E, mesmo assim, os estudos propostos em "Psicanálise da Sociedade Contemporânea" (1955) e “Anatomia da Destrutividade Humana” (1973) questionariam esta hipótese.

Ocorre que esta limitação quanto ao objeto - que provoca, em consequência, uma redução em relação ao método -, (primeiro) contraria a matriz crítica que funda o pensamento de Fromm; (segundo) ignora o salto qualitativo provocado pela teoria crítica na análise dos fenômenos sociais, em sentido amplo; e (terceiro) esquece o giro imposto pela criminologia crítica ao ampliar a lente reduzida ao indivíduo (microcriminologia) para análises concentradas nas relações e formas de exercício do poder (macrocriminologia), no específico.

Desde esta perspectiva, é possível perceber como questões fundacionais do pensamento crítico e que possuem aplicação imediata para a criminologia crítica são abordadas com frequência ao longo da trajetória investigativa de Fromm.

A afirmação de que uma série de reflexões de Fromm, para além dos temas imediatos relativos ao criminoso, ao crime e à pena, é aplicável diretamente ao debate criminológico serve, inclusive, para justificar algumas opções temáticas enfrentadas neste ensaio. Mais: fornecem importantes pistas sobre a constituição e as condições de possibilidade de uma criminologia (crítica) ancorada na Escola de Frankfurt.

A discussão de Fromm sobre a intersecção entre sociologia (Marx) e psicanálise (Freud) permite, no interior das ciências criminais, refletir sobre conexões mais amplas entre criminologia (sociologia do desvio e do controle social) e psicanálise, para além do estudo microcriminológico relativo aos fatores psicológicos que interferem na conduta delitiva (etiologia do crime). Se a criminologia psicanalítica, notadamente a partir dos estudos freudianos, irá concentrar suas investigações em dois temas preferenciais, quais sejam, (primeiro) a psicologia do criminoso ${ }^{69}$ e (segundo) as formas de tradução do diagnóstico do

\footnotetext{
${ }^{68}$ PAVARINI, Massimo. Control y Dominación: teorias criminológicas burguesas y proyecto hegemónico. 2 . ed. Madrid: Siglo XXI, 1988, pp. 18-20.

${ }^{69}$ Freud inaugura os estudos em "Vários Tipos de Caráter Descobertos na Prática Analítica" (1916), no qual identifica os criminosos por sentimento de culpa (FREUD, Sigmund. Varios Tipos de Caracter Descubiertos en la Labor Analitica. Obras Completas, vol. 3. Madrid: Biblioteca Nueva, 1996, pp. 2.413-2.436).
} 
delinquente no sistema de Justiça Criminal $^{70}$; o enlace com materialismo histórico, a partir da Escola de Frankfurt, estimula a reflexão, no plano estrutural, acerca das condições subjetivas de sustentação de determinados modelos político-econômicos, e, no plano institucional, sobre o tipo de controle social e as formas punitivas que the são inerentes.

Neste sentido, a mudança do eixo micro para o macrocriminológico inevitavelmente provoca a alteração do objeto (do estudo da criminalidade ao estudo dos processos de criminalização) e do método (do modelo causal-explicativo ao dialético-interdisciplinar) da ciência criminológica. Assim, na trilha de Fromm, se o caráter social que se desenvolve em determinada cultura não é acidental, mas historicamente determinado, e se está vinculado a um certo sistema político e econômico, igualmente irá impactar a forma e as demandas punitivas (político-criminais). Se o caráter social, como soma dos traços comuns aos indivíduos inseridos na mesma cultura, ao constituir um padrão normativo e modelar as personalidades individuais, reflete a maior ou menor adesão da sociedade à autoridade (opressão) ou à liberdade (emancipação), também irá espelhar as expectativas em relação às formas punitivas. E neste aspecto, o entrelaçamento dialético das análises micro e macro, da psicanálise e da sociologia, é extremamente fértil.

O debate pode ser projetado, inclusive, aos vínculos entre os aparelhos ideológicos e os repressivos do Estado. A família, principal agência psíquica, não atua de forma isolada no processo de socialização. Lembra Rouanet que o aprendizado da autoridade se faz no núcleo familiar, que introjeta na criança a autoridade como personificação da força e como encarnação ética do Bem absoluto. Assim,

uma vez instilada no indivíduo a crença na legitimidade ética do Poder, é fácil aos aparelhos culturais da burguesia reforçar na intensidade desejada esse aprendizado, apresentando o poder econômico e político [criminal] como prolongamentos naturais da autoridade paterna, investidos, como esta, dos atributos da Verdade e do Bem. ${ }^{71}$

A hipótese desenvolvida posteriormente, em 1929, por Alexander e Staub, em "O Criminoso e seus Juízes" (ALEXANDER, Franz; STAUB, Hugo. O Criminoso e seus Juízes. Rio de Janeiro: Guanabara, 1934, pp. 125-182 e, especificamente, pp. 189-201).

${ }_{70}$ Freud realiza esta análise inicialmente em 1906, em "A Psicanálise e o Diagnóstico dos Fatos nos Procedimentos Judiciais" (FREUD, Sigmund. El Psicoanalisis y el Diagnostico de los Hechos en los Procedimientos Judiciales. Obras Completas, vol. 2. Madrid: Biblioteca Nueva, 1996, pp. 1.276-1.2832.436). Em 1930, aprofunda o estudo em "A Perícia Forense no Processo Halsmann" (FREUD, Sigmund. La Peritación Forense en el Proceso Halsmann. Obras Completas, vol. 3. Madrid: Biblioteca Nueva, 1996, pp. 3.072-3.073).

${ }^{71}$ ROUANET, Sérgio. Teoria Crítica e Psicanálise. Rio de Janeiro: Tempo Brasileiro, 1986, p. 65. 
Compreender os discursos de legitimação dos poderes, dentre eles a do poder punitivo, implica, portanto, na perspectiva inaugurada por Fromm, uma análise interdisciplinar que interseccione o estudo da formação da personalidade (autoritária) e do caráter social (fascista) com o sistema político-econômico (capitalista patriarcal).

\section{FROMM: CRIMINOLOGIA CRÍTICA COMO CRÍTICA DA PENA EM “O ESTADO COMO EDUCADOR: SOBRE A PSICOLOGIA DA JUSTIÇA CRIMINAL” (1930)}

A originalidade do mergulho de Fromm na questão punitiva realizada em "O Estado como Educador" (1930), conforme destaca Anderson, se deve sobretudo a dois direcionamentos teóricos: (primeiro) estender as categorias do marxismo-freudiano (não apenas do freudismo) ao estudo do crime (da pena e da punição, acrescente-se); e (segundo) demarcar o problema do delito como um tema social, para além da ênfase positivista, no indivíduo ou nos grupos criminosos (microcriminológica). ${ }^{72}$

Conforme destacado, o estudo de Fromm é anterior ao trabalho "Punição e Estrutura Social" (1939), considerado o marco inaugural da criminologia crítica. ${ }^{73}$ Logicamente que o ensaio de Fromm não se equipara, em profundidade e extensão, à análise apresentada por Rushe e Kirchheimer. De igual forma, é importante lembrar que o debate sobre a questão punitiva já estava colocado na Escola de Frankfurt, neste mesmo período: Rushe realiza as pesquisas-base de "Punição e Estrutura Social" no final dos anos 1920 e publica "Motins Carcerários ou Políticas Sociais (a propósito dos acontecimentos na América do Norte)" "74, "Frankfurter Zeitung", em 1930, e "Mercado de Trabalho e Execução Penal (reflexões para uma sociologia da Justiça Penal)"75, no periódico oficial do Instituto de Pesquisas Sociais, o "Zeitschrift für Sozialforschung”, em 1932.

Logicamente que a investigação contemporânea desenvolvida por Rushe em nada desqualifica o mérito do trabalho de Fromm. Inclusive porque Fromm aborda o problema desde a

\footnotetext{
72 ANDERSON, Kevin. The Young Erich Fromm's Contribution to Criminology. Justice Quarterly, v. 15, n. 04, 1998, p. 678.

${ }^{73}$ A tese de Franz Neumann, orientada por Max Ernst Mayer, em 1922, parece ser o trabalho pioneiro na interpretação materialista das funções da pena (NEUMANN, Franz. Rechtsphilosophische Einleitung zu einer Abhandlung über das Verhältnis von Staat und Strafe. Diss. jur., Faculdade de Direito, Universidade de Frankfurt, Frankfurt am Main, 1922.

74 RUSCHE, Georg. Motines Carcelarios o Politica Social (a propósito de los acontecimientos en norteamerica). Doctrina Penal, v. 07, n. 26, 1984, pp. 265-274.

75 RUSCHE, Georg. Mercado de Trabajo y Ejecución Penal (reflexiones para una sociologia de la justicia penal). Derecho Penal y Criminologia, v. 06, n. 19, 1983, pp. 95-109.
} 
psicologia social analítica, enquanto Rushe, seguindo a tradição marxista ortodoxa, concentra sua análise na economia política do castigo.

Mas apesar de Rushe e Fromm estabelecerem parâmetros de análise distintos, com pontos de partida e de chegada próprios, enfrentam o mesmo objeto (punição) inspirados, indiscutivelmente, pelo mesmo pano de fundo teórico (materialismo histórico), situação que lhes permite compartilhar duas perguntas que irão atravessar os estudos criminológicos críticos ao longo do século XX: (primeiro) quais as funções reais e as funções declaradas desempenhadas pela punição e pelo sistema de justiça criminal nas sociedades capitalistas? e (segundo) quais os efeitos reais e simbólicos que a criminalização e a punição exercem sobre a sociedade na prevenção do crime?

Fromm, a partir do confronto entre os discursos oficiais legitimadores da pena (funções declaradas) e a realidade empírica da punição, parte de um pressuposto que, embora bastante usual na crítica criminológica atual, é inovador: os sistemas de justiça criminal são ineficazes e inadequados para atingir os seus próprios objetivos. Neste cenário, pontua: quais os motivos pelos quais a sociedade se apega irracionalmente, mas com tamanha determinação, a medidas comprovadamente estéreis, impróprias? $^{76}$

Marques Neto chama a atenção para o fato de que a lógica penal inevitavelmente varia em função dos diferentes pontos de partida, que incluem a concepção do direito penal, 0 conceito de delito, a natureza e as modalidades da pena. Ocorre que em paralelo aos dados lógicos, existem outros elementos subjetivos e inconscientes que provocam inflexões nesta racionalidade, "fazendo, com frequência, que ela seja atravessada por uma outra lógica, na qual ficam suspensos princípios fundamentais, como os princípios aristotélicos da identidade e da não-contradição (...)", tão caros à teoria tradicional. Assim, conclui o autor, "para a psicanálise o que mais importa é que aquilo que esteja sendo dito pelo sujeito possa significar outra coisa."77 Neste cenário, se no processo criminal aquilo que está realmente em julgamento é coisa distinta daquilo que está sendo julgado - conforme é demonstrado por Freud na distinção entre “conteúdo manifesto” e “conteúdo latente”78 -, em relação à punição, o que interessa,

\footnotetext{
${ }^{76}$ FROMM, Erich. The State as Educator: on the Psychology of Criminal Justice (1930). In: ANDERSON, Kevin; QUINNEY, Richard (eds.). Erich Fromm and Critical Criminology: beyond the punitive society. Chicago: University of Illinois Press, 2000, p. 124.

${ }_{77}$ MARQUES NETO, Agostinho Ramalho. O Estrangeiro: a Justiça Absurda. In: COUTINHO, Jacinto Nelson de Miranda (coord.). Direito e Psicanálise: interseções a partir de 'O Estrangeiro' de Albert Camus. Rio de Janeiro: Lumen Juris, 2006, p. 15.

78 FREUD apud MARQUES NETO, Agostinho Ramalho. O Estrangeiro: a Justiça Absurda in COUTINHO, Jacinto Nelson de Miranda (coord.). Direito e Psicanálise: interseções a partir de ' $O$ Estrangeiro' de Albert Camus. Rio de Janeiro: Lumen Juris, 2006, p. 16.
} 
realmente, é o não-dito, é aquilo que está encoberto na aparência discursiva. E são as funções reais que o sistema punitivo exerce no corpo social e nas estruturas política e econômica que justificam a permanência da pena como instituição jurídica, para além das evidências da sua total ineficiência em relação às funções declaradas.

O sistema de justiça criminal moderno, segundo Fromm, pensa a si mesmo - a construção verbal mais adequada talvez fosse "apresenta a si mesmo" - como uma espécie de pedagogia ao renunciar os discursos de vingança (teorias absolutas ou retributivas) e sustentar, como objetivo da pena, a reforma ou a correção do criminoso (teorias relativas ou de prevenção). A reforma ou correção seria alcançada através de uma dupla orientação: (primeiro) negativa, como um meio para intimidar e dissuadir os membros do corpo social (prevenção geral negativa); e (segundo) positiva, como sistema de recompensas e discursos de elevação moral para educar o infrator a ser uma pessoa socialmente útil (prevenção especial positiva).

Segundo Fromm, os dados empíricos sobre a experiência dos sistemas penais modernos não apenas demonstram que os métodos tradicionais de intervenção penal são ineficazes, como evidenciam que são inatingíveis, ou seja, não cumprem e sequer poderiam cumprir as finalidades declaradas.

Fromm procura validar sua hipótese a partir da análise de duas situações distintas: os crimes patrimoniais e os crimes sexuais. Em relação aos crimes patrimoniais, sustenta que a violação da lei decorre, fundamentalmente, de uma situação de carência material (fome e outras necessidades elementares). Nestes casos, portanto, “a única possibilidade [de redução e prevenção do crime] é uma elevação da situação econômica do criminoso ao ponto em que a sua situação seja tão segura que o cometimento do crime para satisfazer necessidades elementares é desnecessária."79 Por outro lado, em relação aos delitos sexuais, o autor sustenta que o sistema de penas tem uma eficácia limitada, pois a psicanálise teria demonstrado que “(...) poucas ações que são em realidade causadas por impulsos inconscientes podem ser prevenidas influenciando as pessoas no nível consciente da sua personalidade" ${ }^{80}$, o que seria aplicável para criminosos e não-criminosos neuróticos.

\footnotetext{
79 " (....) the only possibility is an improvement in the economic situation of the 'criminal' to the point where his situation is so secure that committing a crime to gratify elementary needs is unnecessary" [FROMM, Erich. The State as Educator: on the Psychology of Criminal Justice (1930). In: ANDERSON, Kevin; QUINNEY, Richard (eds.). Erich Fromm and Critical Criminology: beyond the punitive society. Chicago: University of Illinois Press, 2000, p. 124].

80 “(...) few actions which are in reality caused by unconscious impulses can be prevented by influencing people at the conscious level of their personality" [FROMM, Erich. The State as Educator: on the Psychology of Criminal Justice (1930). In: ANDERSON, Kevin; QUINNEY, Richard (eds.). Erich Fromm and Critical Criminology: beyond the punitive society. Chicago: University of Illinois Press, 2000, p. 124].
} 
A abordagem diferenciada dos crimes patrimoniais e sexuais permite avançar em uma direção sugerida, porém não desenvolvida expressamente por Fromm, e que será tema de exploração recorrente da crítica criminológica após os anos 1960. Fica evidente, em ambas as explicações, que a realidade empírica e as dinâmicas que envolvem e caracterizam os crimes patrimoniais e sexuais são autônomas. Não apenas porque as circunstâncias de cada delito lhes são próprias, mas porque os fatores que tornam um sujeito vulnerável à prática do furto são distintos daqueles que potencializam a violação sexual. Mais: o sentido produzido pela pena, nas condutas futuras dos autores destes delitos, é igualmente ímpar. Assim, é possível concluir, a partir de Fromm, não apenas que (primeiro) o delito não pode ser tomado como um universal, pois a única identidade possível entre o furto e o estupro (e o homicídio e a sonegação fiscal e a fraude à licitação e o aborto et coetera) é exclusivamente o fato serem condutas adjetivadas artificial e normativamente como delitos - o crime, como realidade natural, não existe; o que de fato existem são condutas arbitrariamente selecionadas e qualificadas como crime ${ }^{81}$-; mas que (segundo) a pena, como resposta jurídica ao delito, não possui qualquer capacidade totalizante, ou seja, as funções que a punição efetivamente realiza só podem ser medidas na concretude da situação real, conforme o sujeito e o fato praticado, sendo impossível atribuir-lhe uma finalidade geral e abstrata.

Nestas condições, a indagação primeira de Fromm adquire um sentido ainda mais relevante: se é comprovadamente ineficaz para atingir suas finalidades, quais as razões que justificam o apego social irrestrito à pena criminal?

Em realidade, as sanções criminais não são dirigidas aos criminosos, nem mesmo aos potenciais. É ilusório pensar, portanto, o sentido da punição a partir dos sujeitos envolvidos em crimes, notadamente porque crime e castigo são fenômenos autônomos, linhas paralelas que não se cruzam. Não apenas a pena não é o resultado natural do delito como o delito não é prevenido com a aplicação da pena.

Por esta razão, Fromm entende que antes de produzir uma função interna no sistema de justiça criminal, a punição, como realidade e experiência, adquire um sentido psíquico na estabilização da estrutura social, ${ }^{82}$ ou seja, a pena atua na produção de uma subjetividade conformista e subordinada aos poderes instituídos.

\footnotetext{
81 Neste sentido conferir, exemplificativamente, HULSMAN, Louk. Criminología Crítica y Concepto de Delito. Abolicionismo Penal. Buenos Aires: Ediar, 1989, pp. 87-107.

82 Segundo Fromm, a estabilidade da estrutura social não pode depender apenas das "forças dos instrumentos externos de poder" (exército e polícia, p. ex.), pois tais agências atuam apenas quando há um risco externo de preservação da sociedade, como nos dados de guerra ou revolução. A pena criminal, portanto, adquire o papel de instrumento interno de poder (FROMM, Erich. The State as Educator: on the
} 
Para compreender esta aporia representada pela consciência social da incapacidade preventiva da pena que se agrega à necessidade (irracional) da sua preservação como instrumento de controle, Fromm recorre à psicanálise, fundamentalmente à atitude psíquica da criança em relação ao pai. Segundo Fromm, o medo da autoridade é uma das condições para que a criança desenvolva os sentimentos de admiração e de adoração ao pai. Aliás, em "Autoridade e Família" (1936), o autor irá sustentar, como fato sociológico, que o pai é, desde o início, o representante da autoridade externa - "o pai de família constitui para a criança, em termos cronológicos, o primeiro mediador da autoridade social, mas é, em termos de conteúdo, sua cópia (Abbild) e não o seu modelo (Vorbild)." 83 O corpo social, seguindo este modelo da relação da criança com a figura paterna, estrutura-se na necessidade de manutenção de relações sociais hierarquizadas e de subordinação das massas às instituições, o que significa, em última análise, uma rigorosa renúncia aos instintos (Triebverzicht).

Nas palavras de Fromm:

essa atitude psíquica [seelische Einstellung] da criança perante o pai é a mesma que o Estado deseja e considera necessária entre a grande massa de cidadãos. 0 Estado deve usar todos os meios possíveis para apresentar-se às massas como uma figura paterna [Vaterimago]. ${ }^{84}$

O sistema de justiça criminal, portanto, como imagem institucional de autoridade, através da imposição do medo e da exigência de respeito, representaria um dos métodos de presentificação do pai no corpo social. Exatamente por esta razão, pouco importam os efeitos reais das suas técnicas de controle (no caso, a pena) sobre os criminosos. Como instituição do Estado, a justiça criminal impõe-se como figura paterna no inconsciente das massas. 0 poder institucional de punir seria o reflexo, em escala social, da renúncia aos instintos, representada na ameaça de castração imposta à criança (complexo de castração). ${ }^{85}$

Psychology of Criminal Justice (1930). In: ANDERSON, Kevin; QUINNEY, Richard (eds.). Erich Fromm and Critical Criminology: beyond the punitive society. Chicago: University of Illinois Press, 2000, p. 125).

${ }^{83}$ FROMM apud ROUANET, Sérgio. Teoria Crítica e Psicanálise. Rio de Janeiro: Tempo Brasileiro, 1986, p. 64.

84 "This psychic attitude [seelische Einstellung] of the child toward the father is the very one that the state desires and considers necessary among the great mass of its citizens. The state must use every possible means to present itself to the masses as a father image [Vaterimago]" [FROMM, Erich. The State as Educator: on the Psychology of Criminal Justice (1930). In: ANDERSON, Kevin; QUINNEY, Richard (eds.). Erich Fromm and Critical Criminology: beyond the punitive society. Chicago: University of Illinois Press, 2000 , p. 125.

85 “O complexo de castração, além da renúncia parcial à masturbação, implica o abandono dos desejos edipianos: nisso ele [Freud] assinala, para o menino, a saída do Édipo e a constituição, através da identificação com o pai ou seu substituto, no núcleo do supereu, que Freud resume na fase lapidar de 
Os exemplos mais evidentes da incorporação simbólica da autoridade do pai pelo Estado, através dos mecanismos do direito penal, são a possibilidade da imposição da pena de morte e o consequente direito ao perdão (graça) dos sentenciados.

Mas para além desta presentificação do pai, Fromm aponta ainda uma segunda justificativa para a necessidade de manutenção da pena criminal como instituição pública, apesar das evidências da sua ineficácia. Se no plano simbólico o desempenho da função paterna pelas instituições formais pode estar em harmonia com modelos mais horizontais e, consequentemente, democráticos de exercício do poder, a segunda função atribuída por Fromm caracteriza o autoritarismo.

Lembra Rouanet que as estruturas sadomasoquistas encontram na família patriarcal pequeno-burguesa suas condições ideais, pois a forma de a criança conseguir evitar a punição e garantir o amor dos pais é através da submissão incondicional à autoridade. No entanto, “com o tempo, o medo à punição transforma-se em seu contrário, e o sofrimento se converte em fonte de prazer, na medida em que contribui para minorar os sentimentos de culpa resultantes da hostilidade contra o pai." ${ }^{\prime 66} \mathrm{E}$ foi essa família (patriarcal pequeno-burguesa), atuando como agência psíquica da sociedade, que produziu o caráter sadomasoquista necessário para a emergência do nazismo.

Não é difícil perceber, portanto, como o sistema de justiça criminal, notadamente quando narcotizado pela crença do populismo punitivo, ao concentrar na pena criminal a exclusividade da resposta aos conflitos sociais, ratifica e legitima a perversão sadomasoquista que Fromm identifica como característica dos sistemas autoritários: (primeiro) no plano individual, como base pulsional da personalidade autoritária; e (segundo) na esfera coletiva, como expressão do caráter social. O culto à autoridade e a crença na legitimidade ética do poder constituem o cimento ideológico que permite a edificação autoritária dos aparelhos formais de controle social (aparelhos repressivos do Estado) e, em consequência, que autoriza o uso da violência extrema como forma de satisfação libidinal, de gozo.

Neste cenário, Fromm afirma que a punição

provê às massas uma forma de gratificação dos seus impulsos sádicos - e é muito importante para os governantes que estes impulsos sejam desviados de si mesmos

1925: '... o complexo de Édipo naufraga pela ameaça de castração'.” (ROUDINESCO, Elisabeth; PLON, Michel. Dicionário de Psicanálise. Rio de Janeiro: Zahar, 1998, p. 106)

${ }^{86}$ ROUANET, Sérgio. Teoria Crítica e Psicanálise. Rio de Janeiro: Tempo Brasileiro, 1986, p. 64. 
para outros objetos - e, ao mesmo tempo, compensa o corpo social, com uma certa equivalência, pela renúncia aos seus instintos. ${ }^{87}$

Adverte, pois, que aquilo que é vulgarmente identificado como sentimento de justiça das massas nada mais é do que a expressão de impulsos libidinais sádicos. A agressividade que caracteriza este tipo de expressão popular de justiça é - especialmente em contextos autoritários, acrescente-se - incorporada pelo sistema punitivo, de forma a satisfazer os impulsos sociais sem criar riscos ou produzir danos aos interesses do Estado.

Em conclusão, Fromm sublinha que o significado primordial da justiça criminal, encoberto pelos discursos de proteção da sociedade e da reforma dos criminosos, é o de influenciar psicologicamente o corpo social, satisfazendo seu gozo libidinal. Assim, o usual discurso da ineficácia da justiça em relação ao crime dificilmente conduzirá a uma mudança enquanto as condições de existência da estrutura social prevalecerem. A sociedade necessita do sistema punitivo como um instrumento de “educação" (Erziehung) das massas, impondo-lhes artificialmente as condições pelas quais a pessoa é "educada" (erzogen): "a condição da criança que reverencia o pai." 88

\section{CONCLUSÃO}

\section{A ATUALIDADE DA CRÍTICA CRIMINOLÓGICA DE ERICH FROMM}

Os problemas propostos pelo jovem Fromm, na série de estudos que compreende os textos do final dos anos 1920 até a publicação de “Medo à Liberdade" (1941), são inovadores no campo criminológico em relação ao objeto e ao método. No que tange ao objeto, junto com Rushe, Kirchheimer e Neumann, Fromm realiza o salto qualitativo característico da crítica ao superar a microcriminologia positivista (análise da criminalidade) e inserir o debate no campo macrocriminológico (análise das instituições punitivas e dos processos de criminalização). Quanto ao método, a adesão à tradição de pesquisa interdisciplinar da Escola de Frankfurt

\footnotetext{
87 "It provides the masses with a form of gratification of their sadistic impulses - and it is very important for the rulers that these impulses be diverted from them and onto another object - and at the same time provides the masses with a certain equivalent for their instinctual renunciation" [FROMM, Erich. The State as Educator: on the Psychology of Criminal Justice (1930). In: ANDERSON, Kevin; QUINNEY, Richard (eds.). Erich Fromm and Critical Criminology: beyond the punitive society. Chicago: University of Illinois Press, 2000, p. 126].

88 "It is the situation of the child who reveres the father" [FROMM, Erich. The State as Educator: on the Psychology of Criminal Justice (1930). In: ANDERSON, Kevin; QUINNEY, Richard (eds.). Erich Fromm and Critical Criminology: beyond the punitive society. Chicago: University of Illinois Press, 2000, p. 127].
} 
permite a intersecção entre materialismo histórico e psicanálise e seu deslocamento para 0 campo das ciências criminais.

Mas para além da validade teórica ou da confirmação empírica das conclusões relativas às funções desempenhadas pela punição na sociedade capitalista - (primeira) presentificação da figura paterna; e (segunda) satisfação libidinal das pulsões sadomasoquistas) -, uma das virtudes mais evidentes de "O Estado como Educador" (1930) pode ser verificada nos seus pontos de partida, nas indagações que movem o autor: se as funções declaradas da pena são inegavelmente irrealizáveis, por qual razão as instituições e, sobretudo, o corpo social, necessitam destes discursos de justificação? Se os efeitos reais produzidos pela punição são totalmente distintos da programação oficial que a sustenta (racionalidade penal), qual o sentido simbólico que desempenha? Por que a sociedade demanda de forma irracional, mas ao mesmo tempo com vigor, medidas comprovadamente ineficazes?

$\mathrm{Na}$ longa investigação coordenada por Theodor Adorno, nos anos 1945 e 1946, nos Estados Unidos, ao serem enfatizados os mecanismos e o papel da propaganda antidemocrática na formação da personalidade autoritária, os pesquisadores indagam, de forma similar as proposições de Fromm: “por que as pessoas se enganam tão facilmente?" "por que aderem ativamente a determinadas ideologias?" Sobretudo no caso do fascismo, uma ideologia que, pela sua própria natureza, favorece uma minoria específica contra a massa que a sustenta. ${ }^{89}$

Em realidade, as questões propostas por Fromm, do ponto de vista da análise teórica do sistema de justiça criminal, podem valer muito mais do que os insights apresentados como resposta. Em um momento no qual o correcionalismo, como discurso relativo de prevenção especial positiva, se apresenta (primeiro) como uma radical alternativa aos modelos liberais clássicos de retribuição (teorias absolutas) e de coerção psicológica (teorias relativas de prevenção geral negativa) e, sobretudo, (segundo) como uma inovação humanista de inspiração social $^{90}$, a opção de Fromm em buscar o sentido não-declarado e as funções simbólicas da pena é, inegavelmente, desestabilizadora. Revela, de maneira bastante evidente, o espírito crítico que move a sua curiosidade intelectual.

89 ADORNO, Theodor W. Estudos sobre a Personalidade Autoritária. In: ADORNO, Theodor W. Obra Completa: Estudos Sociológicos II, v. 9, n. 1, Madrid: Akal, 2009, p. 165.

90 Dois trabalhos são exemplares para compreender o contexto histórico em que o correcionalismo se apresenta como uma proposta político-criminal oposta ao liberalismo: (primeiro) a proposição socialista de Pachukanis (PACHUKANIS, Evgeny. Teoria Geral do Direito e Marxismo. São Paulo: Acadêmica, 1988, pp. 117-136); e (segundo) a perspectiva social-democrata de Radbruch (RADBRUCH, Gustav. Filosofia do Direito. 6. ed. Coimbra: Arménio Amado, 1979, pp. 313-40). 
Além disso, ao evidenciar a falácia dos discursos penais preventivos decorrente da ausência de demonstrabilidade empírica da sua eficácia, Fromm capta, ainda que intuitiva e indiretamente, uma tendência altamente autoritária nas práticas sempre ideológicas da teoria do direito penal: a justificação do injustificável, ponto de partida e ponto de chegada da razão ardilosa. ${ }^{91}$

Mas se as perguntas são altamente provocativas, as respostas propostas pelo jovem Fromm não deixam de apresentar um conteúdo instigante. Por mais que em sua trajetória teórica não tenha submetido, novamente, suas hipóteses relativas à punição a uma reanálise ou a um aprofundamento conceitual e metodológico, na própria tradição da teoria crítica é possível encontrar alguns elementos de diálogo, validação ou reforço. Não necessariamente vinculados às teses sobre a presentificação da figura paterna e do sadomasoquismo, mas relacionadas sobretudo às formas de racionalização e de adesão dos discursos e à dinamização de práticas autoritárias.

O comprometimento com o fascismo - assim como a incorporação e reprodução dos discursos de justificação da punição - se explica não apenas pelos fatores situacionais de ordem sociopolítica e econômica. Demonstra Casara que a naturalização do autoritarismo se insere em uma tradição composta por convicções políticas, econômicas e sociais que formam um padrão antidemocrático. ${ }^{92}$

Assim, compreender os fenômenos do fascismo e do gozo punitivo também requer análises profundas da condição humana interior. Conforme destaca Adorno, é necessário investigar essas necessidades emocionais, os desejos e os medos mais primitivos e irracionais, sobretudo as potencialidades antidemocráticas da massa. ${ }^{93}$

Na proposição de Fromm, a presentificação da figura paterna, primeira função da pena, é vinculada exatamente ao sentimento de medo à autoridade. A subordinação aos poderes institucionais, conforme exposto, reproduz no plano social a relação da criança com o pai e reflete a renúncia aos instintos pela ameaça de castração.

Ao avançar na hipótese de Fromm, duas questões poderiam ser colocadas sobre esta necessidade de presentificação da figura paterna desempenhada pela instituição penal:

\footnotetext{
91 SOUZA, Ricardo Timm. O Nervo Exposto: por uma crítica da razão ardilosa desde a racionalidade ética. Anuário do Programa de Pós-Graduação em Filosofia da PUCRS. Porto Alegre: EDIPUCRS, 2015, p. 352. 92 CASARA, Rubens. Estado Pós-Democrático: neo-obscurantismo e gestão dos indesejáveis. Rio de Janeiro: Civilização Brasileira, 2017, p. 87.

93 ADORNO, Theodor W. Estudos sobre a Personalidade Autoritária. In: ADORNO, Theodor W. Obra Completa: Estudos Sociológicos II, v. 9, n. 1, Madrid: Akal, 2009, p. 165.
} 
(primeira) reflete a priori uma função de infantilização do corpo social? e (segunda) legitima necessariamente práticas autoritárias na resolução dos conflitos?

A resposta para ambos os questionamentos parece ser negativa em relação ao a priori e ao necessariamente.

No plano simbólico, o não que a figura paterna representa pode desempenhar uma importante função de amadurecimento do sujeito, com a introjeção dos limites inerentes à civilização e a sublimação dos instintos. Lacan demonstra que o Édipo em Freud indica a passagem da natureza para a civilização,na qual o pai exerce uma função essencialmente simbólica: nomeia e, através desse ato, encarna a Lei. ${ }^{94}$ Neste cenário, a função paterna seria o exercício de uma nomeação que permitiria à criança adquirir sua identidade. ${ }^{95} \mathrm{O}$ oposto de um processo de infantilização do sujeito, pois.

No entanto, como precisamente assinalado por Casara, em épocas de crise do simbólico e de inegável enfraquecimento dos valores democráticos, as demandas de restauração da “lei do pai” reforçam a epistemologia inquisitiva e o substancialismo penal, ou seja, deflagram um poder (paterno) autocrático que se materializa em práticas extremamente violentas, como, $\mathrm{p}$. ex., as políticas institucionais de extermínio de indesejáveis. ${ }^{96}$ Se o enfraquecimento da função paterna em uma sociedade em crise pode significar um aumento da violência no tecido social, a reivindicação autoritária de uma resposta institucional igual ou superiormente violenta conduz, inegavelmente, ao terror de Estado e, em última análise, ao fascismo.

A transposição da figura paterna aos vínculos simbólicos entre sociedade e Estado não legitima, portanto, em si mesma (a priori, necessariamente), relações autoritárias ou democráticas, infantis ou maduras. Inclusive porque o Estado pode presentificar um pai autoritário e violento ("o pai que castiga e cobra obediência”) ${ }^{97}$ ou um pai tolerante e acolhedor.

Em estruturas sociais sem o enraizamento de uma cultura democrática, nas quais não ocorreram rupturas significativas (inclusive no plano simbólico) com práticas institucionais autoritárias - como é o caso da maioria dos países da América Latina -, há uma forte tendência de convergirem demandas sociais punitivistas e exercícios expressivamente violentos da força

\footnotetext{
${ }^{94}$ ROUDINESCO, Elisabeth; PLON, Michel. Dicionário de Psicanálise. Rio de Janeiro: Zahar, 1998, p. 542.

${ }_{95}$ ROUDINESCO, Elisabeth; PLON, Michel. Dicionário de Psicanálise. Rio de Janeiro: Zahar, 1998, p. 542.

${ }^{96}$ CASARA, Rubens. O Pai é o Limite: do autoritário à autoridade adequada à Democracia. In: CASARA, Rubens. Processo Penal do Espetáculo: ensaios sobre o poder penal, a dogmática e o autoritarismo na sociedade brasileira. Florianópolis: Empório do Direito, 2015, pp. 116-117.

${ }_{97}$ CASARA, Rubens. O Pai é o Limite: do autoritário à autoridade adequada à Democracia. In: CASARA, Rubens. Processo Penal do Espetáculo: ensaios sobre o poder penal, a dogmática e o autoritarismo na sociedade brasileira. Florianópolis: Empório do Direito, 2015, p. 118.
} 
pelas agências do sistema penal. A pena, portanto, irá adquirir uma função (real) de imposição de sofrimentos, sem quaisquer limites.

Em sentido oposto, em sociedades edificadas sobre fundações democráticas e que valorizam o diálogo em detrimento da força, a função paterna representa um interdito à barbárie, às violências privadas do lupus naturalis (indivíduo), mas, sobretudo, às violências públicas do lupus artificialis (Estado). Significa dizer que a lei fixa limites bastante precisos aos indivíduos, no convívio social, e aos agentes públicos, no exercício das práticas punitivas. 0 limite à resolução violenta e ao uso da força inegavelmente estimula, no plano individual, a autonomia do sujeito e, na esfera pública, o amadurecimento do corpo social e das instituições. Não por outra razão, a tendência nas democracias maduras é a da gradual substituição da pena criminal em suas formas clássicas (retributiva ou preventiva) por formas não violentas de responsabilização penal baseadas em um diálogo entre os envolvidos intermediado (ou facilitado) por outros atores sociais, não necessariamente agentes públicos. Substitui-se, assim, um modelo paternalista autoritário e verticalizado que infantiliza os sujeitos (autor do fato e vítima) ao pressupor sua incapacidade de resolver seus próprios conflitos, por um modelo horizontalizado e plural no qual são criadas condições cognitivas de diálogo e espaços nos quais as pessoas, exercendo sua autonomia, possam definir as melhores condições de responsabilização.

Outra variável é ainda relevante: quanto mais imaturos, tutelados e, consequentemente, infantilizados, mais vulneráveis ficam o sujeito e o corpo social ao engano e às falácias, à crença fundamentalista nos líderes ou partidos carismáticos, à adesão (passiva ou ativa) às ideologias ou, em última análise, aos populismos de todas as ordens. E é exatamente este o caldo de cultura que aprisiona o corpo social aos dogmatismos, dinamiza a obediência cega à autoridade e reforça a fé messiânica nas virtudes dos poderes (razão de Estado).

Neste cenário, não parecem ser tão espantosas as indagações propostas por Fromm sobre a necessidade de o corpo social acreditar em discursos de justificação da pena (racionalizações) comprovadamente ineficazes - e por Adorno - sobre as razões de as pessoas se enganarem facilmente e aceitarem ativamente sistemas de valores autoritários que as oprimem.

A segunda tese penológica de Fromm é a da punição exercer uma função de gratificação aos impulsos sociais sadomasoquistas, de satisfação do gozo irracional e agressivo das massas.

A perversão sádica, na primeira construção freudiana, está vinculada à fantasia sexual e intimamente ligada ao masoquismo. O sadismo seria anterior ao masoquismo e expressaria uma agressividade violenta contra um sujeito transformado em objeto. 
A hipótese de Fromm torna-se adequada à análise dos sistemas penais produzidos em ambientes autoritários, cujas práticas se legitimam através de expectativas e de atitudes igualmente fascistas do corpo social, caracterizando aquilo que a criminologia contemporânea denomina populismo punitivo. Assim, a afirmação do gozo sadomasoquista do público consumidor do sistema punitivo como uma das possibilidades explicativas da função da punição, como uma das dimensões possíveis desta complexa relação entre pena e estrutura social, parece ser parcialmente adequada. Casara, p. ex., ao diagnosticar as subjetividades pós-democráticas, forjadas neste regime igualmente marcado pelo autoritarismo, refere a compulsão pela submissão e pela dominação e o seu reflexo na gestão dos grupos criminalizados. ${ }^{98}$

No entanto, para além do caráter sadomasoquista erógeno vinculado à pulsão de morte, talvez seja possível identificar no nível das neuroses obsessivas outros mecanismos de sustentação desta instituição marcadamente moderna que é a pena criminal.

Apesar de insustentável em razão da ausência de demonstração empírica, conforme defende Fromm ao estabelecer os pontos de partida da sua análise, a crença social no mito do direito penal preventivo não pode ser algo simplesmente desprezável, exatamente pelas funções simbólicas que produz.

Agostinho Ramalho Marques Neto lança um olhar psicanalítico ao problema e indaga (primeiro) no que consiste a prevenção no campo do direito penal e (segundo) se o direito penal preventivo seria compatível com a democracia. Para além dos discursos justificacionistas (discursos oficiais/funções declaradas), a relação entre pena (consequência jurídica do delito) e prevenção (justificativa da pena) poderia ser encontrada em uma certa posição subjetiva. Segundo o autor, a busca constante de evitar riscos - no caso penal, o controle da prática de delitos futuros pelo delinquente (prevenção especial positiva: correcionalismo) ou pelo corpo social (prevenção geral negativa: coação psicológica; prevenção geral positiva: reforço normativo e integração comunitária) - está frequentemente associada aos sintomas neuróticos, notadamente o da neurose obsessiva. ${ }^{99}$

A partir de Freud a neurose obsessiva passou a ser comparada não apenas ao fenômeno da histeria ${ }^{100}$, mas também ao da paranoia. Neste registro, Marques Neto percebe que como o

98 CASARA, Rubens. Estado Pós-Democrático: neo-obscurantismo e gestão dos indesejáveis. Rio de Janeiro: Civilização Brasileira, 2017, p. 89.

${ }^{99}$ MARQUES NETO, Agostinho Ramalho. A Censura da Expressão Linguageira e a Hipertrofia do Direito Penal a Serviço do 'Politicamente Correto'. In: VESCOVI, Renata Conde (coord.). Psicanálise e Direito: uma abordagem interdisciplinar sobre ética, direito e responsabilidade. Vitória: ELPV, 2013, p. 63.

$100 \mathrm{Na}$ psicologia pré-freudiana a obsessão significava o oposto da histeria. No medievo ambos os fenômenos estavam relacionados à possessão e à divisão entre corpo e alma: "no caso da histeria, a 
obsessivo está o tempo todo se prevenindo contra possíveis calamidades, organizando um aparato de auto defesa e cercando-se de uma muralha. ${ }^{101}$ No entanto, segundo o autor, no limite extremo da tentativa de controle e de defesa, a posição do sujeito atinge o patamar delirante na estrutura da paranoia, pois o paranoico projeta para o outro o perigo que o ameaça a partir de dentro e se reposiciona para eliminar o perigo preventivamente. ${ }^{102}$

Não obstante a percepção de Fromm em relação à função de satisfação do gozo sádico realizado pela pena criminal, na atual conjuntura de sobreposição de crises nas democracias ocidentais - no campo político criminal, decorrente da vertiginosa ascensão do populismo punitivo a partir da década de 1990; no campo político, deflagrada pela adesão de inúmeros países às demandas neofascistas -, o direito penal parece igualmente captar um elemento obsessivo extremo que é o do delírio paranoide e, ato contínuo, dinamizá-lo em forma de violência institucional extrema.

A coerência entre as perspectivas e as condições de possibilidade de harmonização das duas hipóteses são temas que o futuro próximo fornecerá elementos para testagem e validação.

A tarefa intelectual de revisitar as fundações e recontar a história da criminologia crítica, que de certa forma é proposta neste ensaio, procura se afastar ao máximo e com vigor de uma certa tendência idealista muito presente na pesquisa tradicional em ciências criminais. Não é incomum encontrar na pesquisa jurídico-criminal e criminológica uma "vontade de origem", um desejo profundo que anima os pesquisadores de encontrar novos elementos capazes de inserir uma nova página em uma história já consolidada e repetida ad nauseam. Não por outra razão, são frequentes as revisitas aos museus penais e criminológicos. 0 problema é que invariavelmente estas revisões históricas servem apenas como reforço às matrizes do direito penal liberal. São poucos os trabalhos que apontam, p. ex., os gérmens antiliberais do liberalismo.

possessão é mais sonambúlica, passiva, inconsciente e 'feminina': é o demônio que se apodera de um corpo de mulher para torturá-lo; na obsessão, ao contrário, ela é ativa e 'masculina': é o próprio sujeito que é internamente torturado por uma força diabólica, embora permaneça lúcido quanto ao seu estado." (ROUDINESCO, Elisabeth; PLON, Michel. Dicionário de Psicanálise. Rio de Janeiro: Zahar, 1998, p. 538) 101 MARQUES NETO, Agostinho Ramalho. A Censura da Expressão Linguageira e a Hipertrofia do Direito Penal a Serviço do 'Politicamente Correto'. In: VESCOVI, Renata Conde (coord.). Psicanálise e Direito: uma abordagem interdisciplinar sobre ética, direito e responsabilidade. Vitória: ELPV, 2013, p. 63.

102 MARQUES NETO, Agostinho Ramalho. A Censura da Expressão Linguageira e a Hipertrofia do Direito Penal a Serviço do 'Politicamente Correto'. In: VESCOVI, Renata Conde (coord.). Psicanálise e Direito: uma abordagem interdisciplinar sobre ética, direito e responsabilidade. Vitória: ELPV, 2013, p. 63. 
O alerta é realizado por Zaffaroni ao comentar a obra de Ferrajoli, "Direito e Razão: teoria do garantismo penal”: é necessário retornar às bases para seguir em frente, para refazer o debate interrompido pelo advento da 'polícia' positivista. ${ }^{103}$

Fromm, em seus primeiros textos, ao conectar Marx e Freud e colocar em dúvida a aparência discursiva que sustenta a funcionalidade do sistema punitivo, fornece importantes chaves de compreensão ao saber criminológico crítico, sobretudo no que diz respeito à decodificação das relações incestuosas entre o positivismo científico (criminológico), o sistema econômico capitalista (capitalismo monopolista) e o regime político fascista.

Retornar às fundações para seguir em frente; revisitar os clássicos da teoria crítica para avançar na crítica criminológica; compreender o passado para tentar sobreviver ao presente. Foram os esforços que motivaram esta escrita.

\section{REFERÊNCIAS}

ADORNO, Theodor W. Estudos sobre a Personalidade Autoritária. In: ADORNO, Theodor W. Obra Completa: Estudos Sociológicos II, v. 9, n. 1, Madrid: Akal, 2009.

ADORNO, Theodor W. Estudos sobre Psicologia Social e Psicanálise. In: ADORNO, Theodor W. Ensaios sobre Psicologia Social e Psicanálise. São Paulo: Unesp, 2015.

ALEXANDER, Franz; STAUB, Hugo. O Criminoso e seus Juízes. Rio de Janeiro: Guanabara, 1934.

ANDERSON, Kevin. The Young Erich Fromm's Contribution to Criminology. Justice Quarterly, v. 15, n. 04, 1998, pp. 667-696.

ANIYAR DE CASTRO, Lola; CODINO, Rodrigo. Manual de Criminología Sociopolitica. Buenos Aires: Ediar, 2013.

CASARA, Rubens. Estado Pós-Democrático: neo-obscurantismo e gestão dos indesejáveis. Rio de Janeiro: Civilização Brasileira, 2017.

CASARA, Rubens. O Pai é o Limite: do autoritário à autoridade adequada à Democracia. In: CASARA, Rubens. Processo Penal do Espetáculo: ensaios sobre o poder penal, a dogmática e o autoritarismo na sociedade brasileira. Florianópolis: Empório do Direito, 2015.

FOUCAULT, Michel. Vigiar e Punir. 8. ed. Petrópolis: Vozes, 1991.

103 “(...) è necessário tornare indietro per riprendere il debattito interrotto con l'intervento dela 'polizia' positivista” (ZAFFARONI, Eugenio Raúl. La Rinascita del Diritto Penale Liberale o la 'Croce Rossa' Giudiziaria. In: GIANFORMAGGIO, Letizia. Le Ragioni del Garantismo: discutendo com Luigi Ferrajoli. Torino: Giappichelli, 1993, p. 384). 
FREUD, Sigmund. El Psicoanalisis y el Diagnostico de los Hechos en los Procedimientos Judiciales. Obras Completas, vol. 2. Madrid: Biblioteca Nueva, 1996.

FREUD, Sigmund. La Peritación Forense en el Proceso Halsmann. Obras Completas, vol. 3. Madrid: Biblioteca Nueva, 1996.

FREUD, Sigmund. Varios Tipos de Caracter Descubiertos en la Labor Analitica. Obras Completas, vol. 3. Madrid: Biblioteca Nueva, 1996.

FROMM, Erich. Anatomia da Destrutividade Humana. 2. ed. Rio de Janeiro: Guanabara, 1987.

FROMM, Erich. El Dogma de Cristo. Barcelona: Paidós, 1994.

FROMM, Erich. Medo à Liberdade. 14. ed. Rio de Janeiro: Guanabara, 1986.

FROMM, Erich. Método e Função de uma Psicologia Social Analítica. In: FROMM, Erich. A Crise da Psicanálise: Freud, Marx e a Psicologia Social. 2 ed. Rio de Janeiro: Zahar, 1977.

FROMM, Erich. Psicanálise da Sociedade Contemporânea. São Paulo: Círculo do Livro, 1985.

FROMM, Erich. Psicanálise e Sociologia. Revista Espaço Acadêmico, n. 110, 2010.

FROMM, Erich. The State as Educator: on the Psychology of Criminal Justice (1930). In:

ANDERSON, Kevin; QUINNEY, Richard (eds.). Erich Fromm and Critical Criminology: beyond the punitive society. Chicago: University of Illinois Press, 2000.

FUNK, Rainer. Erich Fromm's Life and Work. In: ANDERSON, Kevin; QUINNEY, Richard (eds.). Erich Fromm and Critical Criminology: beyond the punitive society. Chicago: University of Illinois Press, 2000.

GARCÍA MENDEZ, Emilio. Pena e Estructura Social en América Latina. Nuevo Foro Penal, v. 22, 1983

HULSMAN, Louk. Criminología Crítica y Concepto de Delito. Abolicionismo Penal. Buenos Aires: Ediar, 1989.

JAY, Martin. A Imaginação Dialética: história da Escola de Frankfurt e do Instituto de Pesquisas Sociais (1923-1950). Rio de Janeiro: Contraponto, 2008.

LA BOÉTIE, Etienne de. O Discurso da Servidão Voluntária. 3. ed. São Paulo: Brasiliense, 1986.

MARQUES NETO, Agostinho Ramalho. A Censura da Expressão Linguageira e a Hipertrofia do Direito Penal a Serviço do 'Politicamente Correto'. In: VESCOVI, Renata Conde (coord.)

Psicanálise e Direito: uma abordagem interdisciplinar sobre ética, direito e responsabilidade. Vitória: ELPV, 2013.

MARQUES NETO, Agostinho Ramalho. O Estrangeiro: a Justiça Absurda. In: COUTINHO, Jacinto Nelson de Miranda (coord.). Direito e Psicanálise: interseções a partir de 'O Estrangeiro' de Albert Camus. Rio de Janeiro: Lumen Juris, 2006. 
MARQUES NETO, Agostinho Ramalho. O Processo Kafkiano. In: COUTINHO, Jacinto Nelson de Miranda (coord.) Direito e Psicanálise: interseções a partir de 'O Processo' de Kafka. Rio de Janeiro: Lumen Juris, 2007.

NEUMANN, Franz. Rechtsphilosophische Einleitung zu einer Abhandlung über das Verhältnis von Staat und Strafe. Diss. jur., Faculdade de Direito, Universidade de Frankfurt, Frankfurt am Main, 1922.

NIETZSCHE, Friedrich. Genealogia da Moral. São Paulo: Companhia das Letras, 1998.

PACHUKANIS, Evgeny. Teoria Geral do Direito e Marxismo. São Paulo: Acadêmica, 1988.

PAVARINI, Massimo. Control y Dominación: teorias criminológicas burguesas y proyecto hegemónico. 2. ed. Madrid: Siglo XXI, 1988.

RADBRUCH, Gustav. Filosofia do Direito. 6. ed. Coimbra: Arménio Amado, 1979.

REIS, Carlos; CARVALHO, Eurico. Introdução à Leitura de Erich Fromm. Revista da Faculdade de Letras da Universidade do Porto, n. 04, segunda série, 1987.

ROUANET, Sérgio. Teoria Crítica e Psicanálise. Rio de Janeiro: Tempo Brasileiro, 1986.

ROUDINESCO, Elisabeth; PLON, Michel. Dicionário de Psicanálise. Rio de Janeiro: Zahar, 1998.

RUSCHE, Georg. Mercado de Trabajo y Ejecución Penal (reflexiones para una sociologia de la justicia penal). Derecho Penal y Criminologia, v. 06, n. 19, 1983.

RUSCHE, Georg. Motines Carcelarios o Politica Social (a propósito de los acontecimientos en norteamerica). Doctrina Penal, v. 07, n. 26, 1984.

SHECAIRA, Sérgio Salomão. Criminologia. 2. ed. São Paulo: Revista dos Tribunais, 2008.

SLATER, Phil. Origem e Significado da Escola de Frankfurt: uma perspectiva marxista. Rio de Janeiro: Zahar, 1978.

SOUZA, Ricardo Timm. A Escola e Frankfurt e o Contexto do seu Surgimento. In: SOUZA, Ricardo Timm. Adorno \& Kafka: paradoxos do singular. Passo Fundo: Ifibe, 2010, pp. 53-54.

SOUZA, Ricardo Timm. O Nervo Exposto: por uma crítica da razão ardilosa desde a racionalidade ética. Anuário do Programa de Pós-Graduação em Filosofia da PUCRS. Porto Alegre: EDIPUCRS, 2015.

WIGGERSHAUS, Rolf. La Escuela de Fráncfort. Buenos Aires: FCE, 2010.

ZAFFARONI, Eugenio Raúl. La Rinascita del Diritto Penale Liberale o la 'Croce Rossa' Giudiziaria. In: GIANFORMAGGIO, Letizia. Le Ragioni del Garantismo: discutendo com Luigi Ferrajoli. Torino: Giappichelli, 1993. 


\section{COMO FAZER REFERÊNCIA AO ARTIGO (ABNT):}

CARVALHO, Salo de. Erich Fromm e a crítica da pena: aproximações entre psicanálise e criminologia desde a teoria crítica da sociedade. Revista Eletrônica do Curso de Direito da UFSM, Santa Maria, RS, v. 14, n. 3, e37766, set./dez. 2019. ISSN 1981-3694. DOI: http://dx.doi.org/10.5902/1981369437766. Disponível em: https://periodicos.ufsm.br/revistadireito/article/view/37766 Acesso em: dia mês. ano.

Direitos autorais 2019 Revista Eletrônica do Curso de Direito da UFSM

Editores responsáveis: Rafael Santos de Oliveira e Angela Araujo da Silveira Espindola

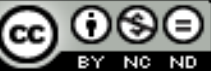

Esta obra está licenciada com uma Licença Creative Commons Atribuição-NãoComercial-SemDerivações 4.0 Internacional.

\section{SOBRE O AUTOR}

\section{SALo de CARvalho}

Professor Adjunto de Direito Penal, Faculdade Nacional de Direito (UFRJ). Professor Permanente do Programa de PósGraduação em Direito da Unilasalle. Mestre em Direito pela Universidade Federal de Santa Catarina (1996). Doutor em Direito pela Universidade Federal do Paraná (2000). Pós-Doutor em Criminologia pela Universitat Pompeu Fabra (Barcelona, ES) (2008-2010). Pós-Doutor em Direito Penal (bolsa CNPq) pela Universitá di Bologna (Bologna, ITA) (2013-2014). Pós-Doutor em Filosofia Política pela Pontifícia Universidade Católica do Rio Grande do Sul (PUCRS) (2014-2016). Autor, dentre outros, dos livros: "Penas e Medidas de Segurança no Direito Penal Brasileiro" (2. ed. São Paulo: Saraiva, 2015); "Antimanual de Criminologia" (6. ed. São Paulo: Saraiva, 2015); "A Política Criminal de Drogas no Brasil" (8. ed. São Paulo: Saraiva, 2016); "Como (não) se faz um Trabalho de Conclusão" (3. ed. São Paulo: Saraiva, 2015) dentre outros. Investiga os temas: Direito Penal, Criminologia, Sociologia do Desvio, Penologia, Política de Drogas, Fundamentos do Processo Penal, Direitos Humanos, Metodologia de Pesquisa, Teoria Crítica. 